\title{
O sector da música popular en Galicia perante a crise da COVID-19
}

DOI: $10.17075 /$ smpgpcc.2020

O avance da crise provocada pola aparición do virus SARS-CoV-2 e a enfermidade da COVID-19, o mantemento do estado de alarma en toda España e o confinamento da sociedade preocúpalles aos responsables do sector da música popular ${ }^{1}$ de Galicia. $O$ feito de tratarse dunha actividade cunha compoñente elevada de socialización e que, ademais, concentre gran parte da actividade arredor da primavera e o verán, supón que sexa un sector especialmente vulnerable a esta crise. Neste traballo recóllense as análises dos responsables das principais asociacións profesionais e gremiais que compoñen o sector da música popular de Galicia, así como unha descrición da situación antes da chegada da crise provocada polo coronavirus e un resumo das principais reivindicacións do sector e da resposta da Administración.

\footnotetext{
${ }^{1}$ Tal e como se establece nas estatísticas do Ministerio de Cultura e Deporte e da Sociedad General de Autores (SGAE), distínguese a música popular da clásica, comprendendo a primeira unha gran cantidade de xéneros dirixidos a audiencias amplas.
}
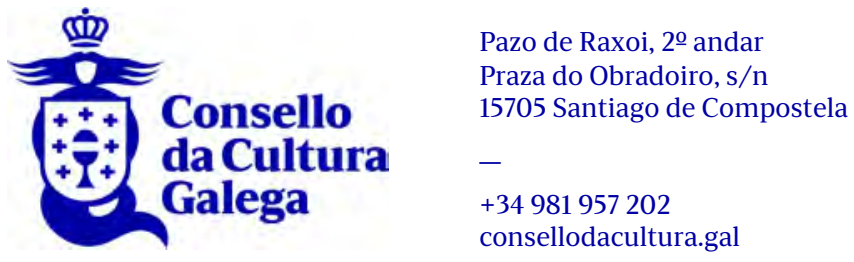


\section{A situación da música popular antes da crise sanitaria}

A música constitúe un dos grandes sectores da cultura. A Conta Satélite da Cultura do IGE confírelle un peso, xunto co resto das artes escénicas, do 12,9\% do total da cultura, o que supón unha produción de 274 millóns de euros e máis de 3.100 postos de traballo.

Se se ten en conta a evolución histórica dos datos referidos á actividade da música popular entre 2003 e 2018, obsérvase un patrón común en relación co número de concertos e de espectadores. O ano 2010, que coincide co último Ano Santo Compostelán, rexistra o maior número de concertos e de espectadores de toda esta serie histórica. Se ben o número de concertos se foi reducindo progresivamente nos seguintes anos ata 2017, para despois aumentar lixeiramente, a cifra de espectadores experimentou un descenso brusco despois de 2010, pero empezou a recuperarse lentamente a partir de 2015.

\section{Concertos e espectadores de música popular en Galicia}

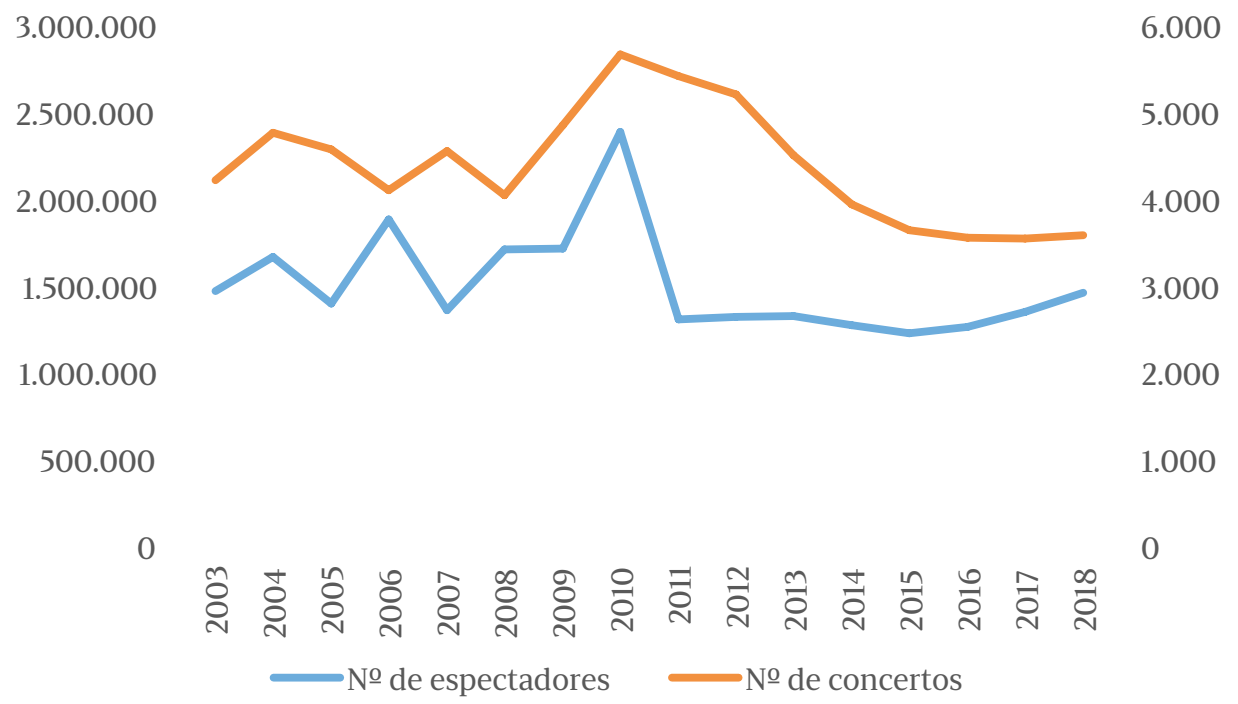

Fonte: SGAE

Durante o ano $2018^{2}$ organizáronse en Galicia un total de 3.585 concertos de música popular (42 concertos máis ca un ano antes), aos que asistiron un total de 1.463 .170 persoas (113.530 espectadores máis). Con estes resultados, cabe destacar que 2018 foi un ano con incrementos do 1,2\% na oferta e do 8,4\% na asistencia a concertos de música. Entre 2018 e 2017, a

\footnotetext{
${ }^{2}$ Incluídos datos de concertos e macrofestivais.
} 
música popular en Galicia amosa unha tendencia positiva, que demostra que o público segue a estar interesado nos concertos de música en vivo e os grandes festivais.

En 2018 obtívose unha recadación de 15.634 .633 euros $(2.893,235$ euros máis), o que supón un incremento do 22,7\% respecto de 2017. A tendencia debuxada dende 2013 resulta moi positiva. Isto poderíase explicar polo diñeiro recadado en parte en grandes festivais que concentran unha cantidade importante de público. Máis recentemente, tamén debeu ter un certo impacto positivo a baixada do IVE nos espectáculos en vivo de 2017.

\section{Recadación dos concertos de música popular en Galicia (euros)}

18.000 .000

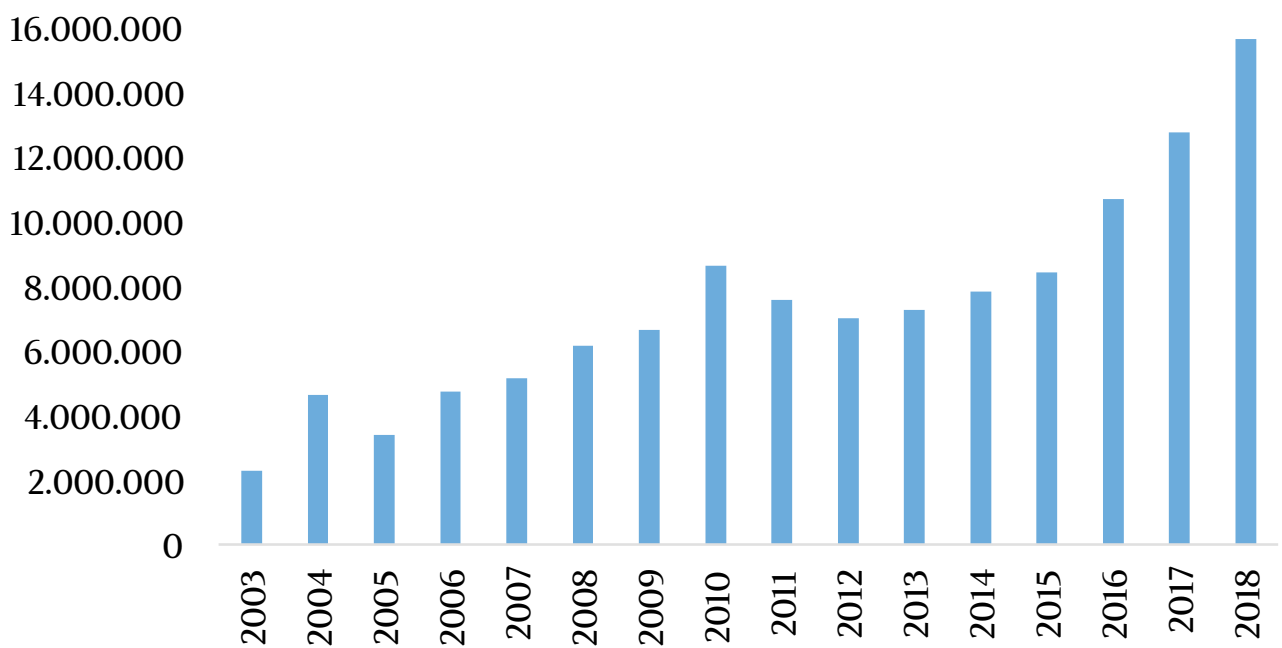

Fonte: SGAE

En relación con isto hai que ter en conta que unha gran cantidade de concertos que teñen lugar en Galicia son de carácter gratuíto e, polo tanto, non se obtén ningunha recadación. A gratuidade dos concertos podería xustificar, por exemplo, que en 2010 se rexistre a maior cifra de concertos e de espectadores da serie histórica pero a recadación obtida nese ano sexa case a metade da de 2018.

Pese a este indicador positivo, o gasto en espectáculos da poboación galega mostra unha evolución decrecente dende 2008 a 2013 e un pequeno incremento irregular dende esa data. Un dato ilustrativo é que cada persoa en Galicia gastaba 47,6 £ de media nestes servizos en 2007 e 35,1 $£$ en 2018. 


\section{Serie enlazada do gasto en espectáculos en Galicia}

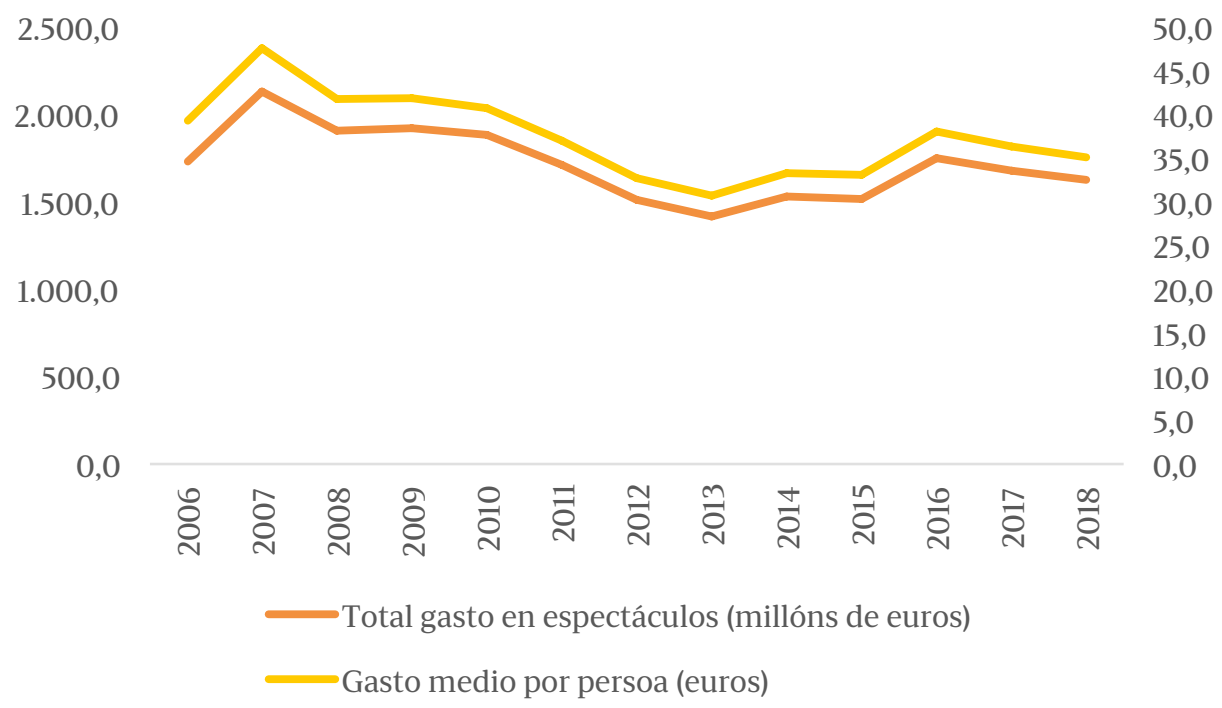

Fonte: MCUD. Explotación de la Encuesta de Presupuestos Familiares. INE. Encuesta de Presupuestos Familiares. Base 2006

En contraste con esa tendencia, o gasto medio por espectador no total das actividades de música popular ao vivo en Galicia non parou de medrar nos últimos anos. A evolución mostra unha pequena contracción entre 2011 e 2013, pero un incremento moi destacable dende esa data ata 2018 que practicamente duplicou a cantidade (de 5,5 $₹$ en 2013 a $10,7 £$ en 2018). 


\section{Gasto medio por espectador en concertos de música popular en Galicia (euros)}

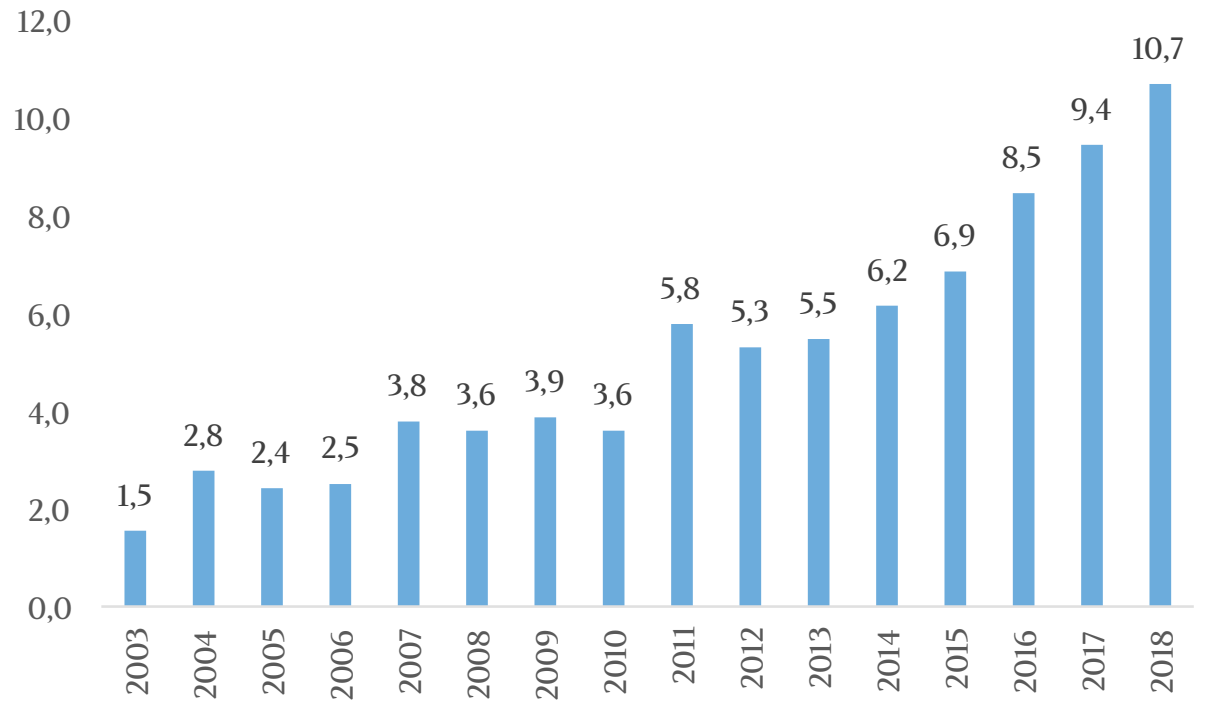

Fonte: Elaboración propia a partir da SGAE

DOCUMENTOS DE TRABALLO CCG
En canto ao gasto público, hai que destacar que dende 2013 na enquisa Estatística de Financiación e Gasto Público en Cultura do Ministerio de Cultura e Deporte só están dispoñibles unhas desagregacións moi pobres para a Administración autonómica en Galicia, polo que non é posible coñecer o gasto liquidado en música. $O$ gasto liquidado global mostra unha tendencia moi negativa entre 2009 e 2014 e unha pequena recuperación a partir desa data.

Un indicador do gasto público en música pódese obter a partir da estatística de orzamentos do IGE, que ofrece as desagregacións da Axencia Galega das Industrias Culturais (AGADIC), que ten, entre outras competencias, a promoción da música popular en vivo. Malia que esta estatística non permite distinguir que cantidades se destinan á música, si se poden coñecer as partidas destinadas a investimentos reais e a transferencias de capital da axencia. Tal e como se pode apreciar a continuación, prodúcese un descenso moi acusado en 2013 e unha lenta recuperación partir desa data, que sitúa o importe total en 7,4 millóns de euros en 2020. 


\section{Evolución da contía total dos capítulos VI e VII de AGADIC (miles de euros)}

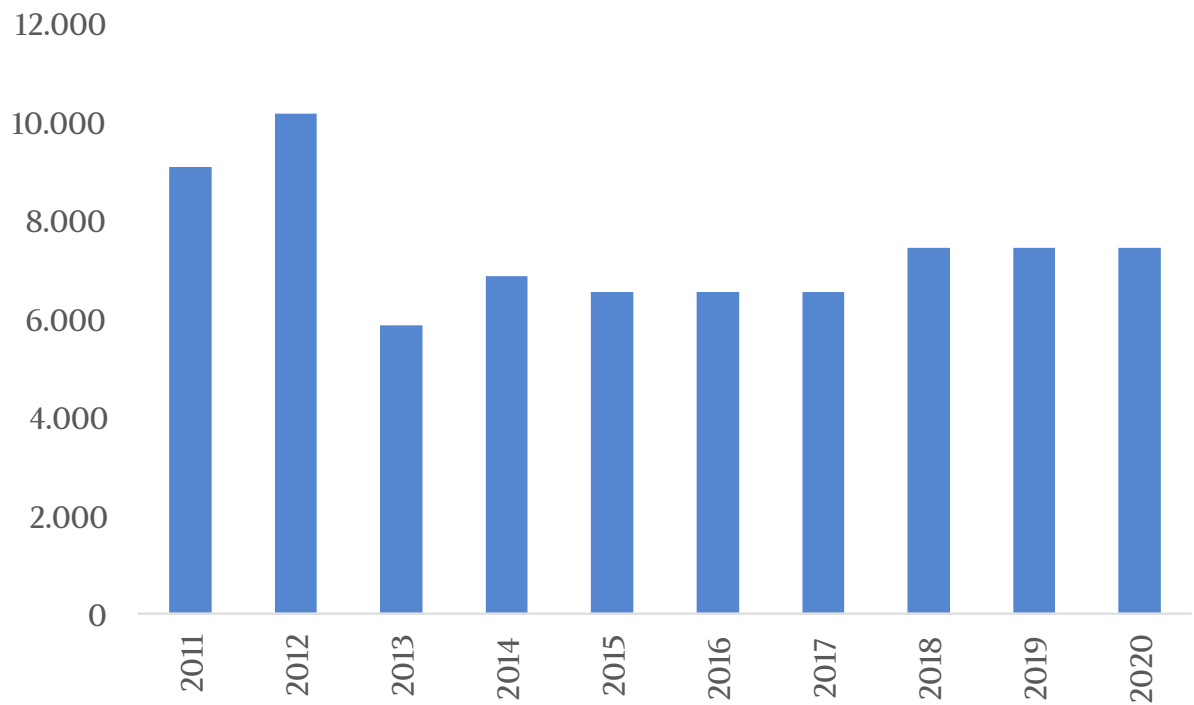

Fonte: IGE (Instituto Galego de Estatística). Axencias públicas de Galicia. Orzamento inicial de ingresos e gastos. Clasificación económica.

Outro dato relevante é a evolución do gasto da Administración local, que é a que soporta en conxunto a maior cantidade de gasto público en cultura. No último ano de referencia (2017), a Administración autonómica galega gastou 75,2 millóns de euros, fronte aos 173,9 millóns da Administración local. A estatística de gasto público en cultura non ofrece unha desagregación no destino de gasto da Administración local que se identifique coa música, dado que non se recolle na estrutura orzamentaria. A continuación, recóllese a evolución do gasto da Administración local en festas populares e festexos, que en moitos casos inclúe a contratación de espectáculos musicais, para que sirva de indicador de tendencia. Lamentablemente, esta epígrafe só está dispoñible dende 2015. 


\section{Gasto en festas populares e festexos da Administración local en Galicia (miles de euros)}

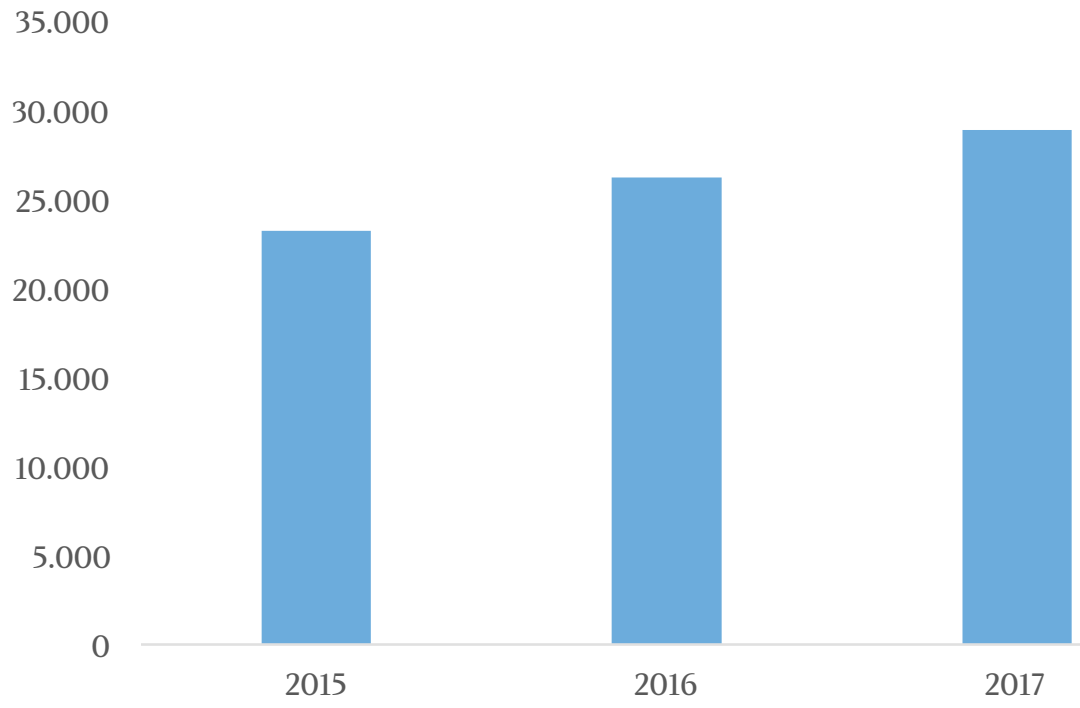

Fonte: MCUD. Estadística de Financiación y Gasto Público en Cultura, MHAC. Estadística de Liquidación de los Presupuestos de las Entidades Locales

O incremento porcentual desta partida foi do $12,8 \%$ en 2016 e do $10 \%$ en 2017, para situarse en 28,9 millóns de euros.

O impacto económico da música popular é moi destacable. Malia non contar con estudos específicos sobre a totalidade do sector, é posible comprender a súa dimensión a partir de traballos parciais. Por exemplo, algúns dos festivais reunidos baixo a marca FEST Galicia, creada pola Xunta de Galicia para promover o territorio galego como destino musical, foron obxecto de estudos de impacto económico na campaña de 2018³. Ese ano, os festivais PortAmérica, Resurrection Fest, Sinsal SON Estrella Galicia, SonRías Baixas e Revenidas tiveron o impacto económico e o retorno de investimento que se pode ver na seguinte táboa:

\footnotetext{
${ }^{3}$ Axencia Galega das Industrias Culturais (2018): Informes de avaliación de impacto dos festivais FEST Galicia. Recuperado de:

http://www.agadic.gal/publicacions/edicion_dixital
} 


\section{Impacto económico global e retorno do investimento dalgúns festivais da marca FEST Galicia ${ }^{4}$}

\begin{tabular}{llll} 
& Conservador & Optimista & ROI Xunta de Galicia \\
\hline PortAmérica & $1.698 .349 €$ & $2.182 .631 €$ & $43,55-55,96 €$ \\
Revenidas & $805.679 €$ & $952.702 €$ & $26,26 €-31,06 €$ \\
Sinsal SON & $504.248 €$ & $646.925 €$ & $17,16 €-22,02 €$ \\
SonRías Baixas & $1.255 .930 €$ & $1.446 .873 €$ & $38,68 €-44,57 €$ \\
Resurrection Fest & $8.534 .061 €$ & $9.456 .439 €$ & $181,58 €-201,20 €$ \\
\hline
\end{tabular}

Fonte: Elaboración propia a partir de AGADIC

Tal e como se pode observar, o impacto económico, mesmo nos cálculos conservadores, é moi significativo e suma cantidades moi relevantes. O retorno de investimento (ROI), calculado a partir da suma dos importes das axudas e subvencións da Xunta de Galicia, é maior canto maior é o evento, e vai dende os 17 euros por euro investido no festival Sinsal aos máis de $180 €$ do Resurrection Fest.

Ademais das bandas e agrupacións que participan dos concertos e macrofestivais, a música popular en vivo en Galicia ten outros actores tamén cunha gran repercusión social e cultural. $\mathrm{O}$ caso das verbenas e orquestras ten unha dimensión considerable en Galicia. Nun estudo de 2010 un subsector composto por 295 agrupacións radicadas en Galicia e outras 25 de fóra da comunidade cunha actividade estable aquí. No que se refire á facturación anual, contabilizáronse 5.743 actuacións e uns 26,2 millóns de euros en actuacións ao aire libre ou en festivais.

Outro subsector importante, pese a ter unha dimensión eminentemente amadora, é o das bandas de música populares. Segundo os datos ofrecidos pola Federación de Bandas de Música Populares, que representa a 94 entidades e 7.124 músicos, aos que hai que engadir outras persoas relacionadas con estas formacións como os directores/as, asociados de cada banda, xestores non músicos, directivos e directivas, alumnado e profesorado das escolas de música

\footnotetext{
${ }^{4}$ Nestes estudos calcúlase o retorno do investimento (ROI) a partir de dous escenarios de impacto económico, un conservador e un optimista.

${ }^{5}$ Axencia Galega das Industrias Culturais (2012): Do palco ó escenario. Unha aproximación analítica á industria da música nas festas populares de Galicia. Recuperado de: http://www.agadic.gal/publicacions/edicion_dixital
} 
xestionadas polas bandas. Este tipo de entidades ingresaron $46.022 €$ de media en 2019, cun incremento do 10,1\% respecto de $2018^{6}$.

Tamén é singular a achega da música tradicional galega ao conxunto da música popular. Da súa relevancia dá conta o Libro Branco do Ensino na Música Tradicional en Galicia ${ }^{7}$, que no momento da súa publicación ofrecía unhas cifras sobre a súa repercusión na sociedade galega: en 2005 sumaba case 1.400 actividades, nas que están inscritas máis de 20.000 persoas, cun profesorado contratado dunhas 640 persoas en case 700 centros de ensino. En Galicia, preto de 250 concellos dos 315 teñen algún tipo de actividade relacionada coa transmisión de música tradicional. En 2018, o 5,2\% dos espectadores de concertos de música popular de Galicia asistiron a concertos de folk, a cuarta comunidade autónoma do Estado despois de Asturias, A Rioxa e Navarra.

\section{Reivindicacións do sector da música popular e resposta da Administración}

As perdas económicas que estiman para o total de España os representantes deste ámbito ${ }^{8}$ superaron entre marzo e maio de 2020 os 130 millóns de euros, coa suspensión dunhas 30.000 funcións, unhas cifras que poderán incrementarse nos vindeiros meses. Esta realidade afecta a un sector que, segundo denuncian as principais asociacións, aínda non se recuperou da crise económica de 2008, a partir da cal a maior parte da produción pasou a mans de pequenas empresas, colectivos ou autónomos, con recursos financeiros moi pequenos, para as que obter unha marxe de beneficio se converteu nun obxectivo difícil. Ante este escenario, o pasado mes de abril, 33 asociacións do ámbito das artes escénicas e musicais asinaron un documento conxunto no que

\footnotetext{
${ }^{6}$ A Federación realizou un estudo preliminar sobre o impacto da COVID-19 nos seus asociados e cre que un $56 \%$ das entidades terá un impacto moderado (haberá problemas importantes pero seguirán en funcionamento) e un $48 \%$ sufrirá un impacto significativo (haberá problemas de solvencia e terá que axustar as e os profesionais contratados). Estiman unha baixada de ingresos de polo menos o 42\% para 2020. Para facerse unha idea da repercusión laboral que isto pode significar, das entidades que responderon ao cuestionario que se elaborou para este estudo (exactamente o $50 \%$ do universo) dependen 270 traballadores/as por conta allea e 56 profesionais autónomos.

${ }^{7}$ Fundación Sondeseu (2006): Libro Branco do Ensino na Música Tradicional en Galicia. Recuperado de http://gaiteirosgalegos.gal/images/files/2015_xan_xun/libro_branco_sondeseu.pdf

${ }^{8}$ VV. AA. (2020): 52 Medidas Extraordinarias para el Sector de las Artes Escénicas y la Música. Recuperado de https://academiadelasartesescenicas.es/396-documento-52medidas-extraordinarias-para-las-artes-escenicas-y-la-musica/
} 
demandan a actuación inmediata e coordinada de todas as administracións públicas.

Nese mesmo documento, o sector da música advertía que a súa volta á actividade non será das primeiras en recuperar a normalidade, posto que esixe a reunión de público. Ademais recoñeceu que, a pesar de que se tomaron medidas económicas audaces, estas non son suficientemente específicas para este colectivo, de características moi distintas ás doutros sectores produtivos, xa que o tipo de traballo é esencialmente estacional e intermitente, o que lle impide acollerse aos plans de axudas e subvencións xerais anunciados polo Goberno. Por todo isto, a práctica totalidade das asociacións que agrupan o tecido cultural español subscribiron un "plan de choque" que recolle 52 medidas extraordinarias que permitan afrontar os efectos derivados da crise sanitaria.

As propostas inclúen un programa de accións en ámbitos como a contratación pública e outras relacionadas coa Seguridade Social, o financiamento empresarial, as subvencións públicas ou os impostos, así como as dirixidas ao fomento do sector. Entre estas medidas pódese salientar, por exemplo, a reprogramación das actuacións suspendidas temporalmente, o pagamento anticipado dunha parte das actuacións aprazadas e a execución íntegra do orzamento de gasto no sector asignado polas diferentes administracións públicas para o 2020. O colectivo tamén propón liñas de crédito oficial en condicións vantaxosas, fondos para cubrir a falta de ingresos e os danos causados polas cancelacións, o aprazamento da débeda tributaria e a redución do IVE no prezo das entradas e as contratacións artísticas.

No ámbito artístico, as asociacións consideran necesario un plan de relanzamento da actividade cando remate o confinamento da poboación, outro de apoio á dramaturxia contemporánea, á creación coreográfica e á composición musical, o sostemento dos circuítos e, en xeral, unha estratexia de fomento das artes escénicas e musicais. Tras estes acordos conxuntos, a industria musical, pola súa parte, continúa a súa actividade a través de numerosas iniciativas e campañas de sensibilización. Profesionais das diferentes ramas do sector, dende artistas, discográficas, tendas de discos ou salas de concertos ata estudos de gravación, están a colaborar para dar a coñecer a problemática do colectivo durante a corentena e a crise da COVID-19. Á marxe dos logros que se acadaron a partir das negociacións con institucións e organismos públicos, a intención dos e das profesionais é a de concienciar ao público de que, grazas á música que milleiros de artistas están a difundir en redes sociais e mediante streaming, a sociedade é capaz de soportar mellor o confinamento. 
Como resposta ás demandas do sector, o pasado día 5 de maio o Consello de Ministros do Goberno central aprobou un Real decreto-lei ${ }^{9}$, polo que se destinaban 76,4 millóns de euros a axudas para o sector cultural e para o financiamento das empresas culturais. Nel tamén se inclúen medidas fiscais, así como o acceso extraordinario á prestación por desemprego para as e os traballadores da cultura que, pola súa intermitencia, non quedaron amparados polos mecanismos de cobertura xa establecidos. Esta medida, moi demandada polos diferentes colectivos, afecta ao $45 \%$ dos contratos de traballo do sector artístico. A duración da prestación é dun máximo de 180 días e poderá ser compatibilizada con outros subsidios da Administración.

No relacionado especificamente co eido das artes escénicas e musicais, este Real decreto-lei inclúe un sistema de axudas extraordinarias de 38,2 millóns de euros, que se concederán por unha soa vez e mediante réxime de concorrencia a través de dúas liñas: ao sostemento das estruturas culturais de toda índole e ás actividades escénicas e musicais e proxectos culturais.

O colectivo de profesionais da música en Galicia trasladou a súa preocupación á Xunta de Galicia a principios do pasado mes de abril nunha xuntanza en que participaron: José Manuel Blanco, presidente da Asociación Galega de Empresas Musicales (AGEM); Manuel Alonso, por Músicas ao vivo; Alberto Grandío, presidente da Asociación Galega de Salas de Música Clubtura; Xabier Alonso, xerente da Asociación de Festivais de Galicia; Paco de Pin, presidente da Asociación de Empresas Tecnolóxicas e Servizos Audiovisuais de Galicia (AGATEC), e Joaquín Martínez, presidente de ESmúsica. Por parte da Consellería, asistiron tamén o director xeral de Políticas Culturais, Anxo M. Lorenzo, e o director da Axencia Galega das Industrias Culturais (AGADIC), Jacobo Sutil. Tras a celebración da reunión, o Conselleiro de Cultura e Turismo, Román Rodríguez González, comprometeuse co sector na axilización dos pagamentos, así como na posta en marcha dunha serie de accións de reactivación adaptadas á evolución da crise sanitaria.

A partir desta primeira xuntanza, o diálogo entre o sector da música e o Goberno galego foi constante durante todo o mes de abril, no que tiveron lugar máis de 65 reunións e se formularon preto de 170 propostas. Como froito destes encontros, o 30 de abril o presidente da Xunta de Galicia, Alberto Núñez Feijóo, comprometeuse a poñer en marcha o chamado "Plan de reactivación da cultura e o turismo”. O plan, consensuado co sector cultural e turístico, presenta 50

\footnotetext{
${ }^{9}$ Real decreto-lei $17 / 2020$, do 5 de maio, polo que se aproban medidas de apoio ao sector cultural e de carácter tributario para facer fronte ao impacto económico e social da COVID-2019.
} 
medidas específicas para o sector e conta cun investimento de 27 millóns de euros co fin de acadar tres obxectivos fundamentais: o fomento do emprego, a xeración de liquidez e a reactivación do consumo. No ámbito cultural en concreto, as actuacións da Administración autonómica centraranse noutros 4 eixes: activación do sector, mantemento do emprego, fomento do consumo e aposta pola formación, profesionalización e mellora da competitividade.

Para poder levar a cabo este plan, a Consellería de Cultura e Turismo reestruturou o seu orzamento e recompuxo as partidas co fin de mellorar as expectativas dos sectores turístico e cultural, tendo en conta que ambos os sectores constitúen o 13\% do PIB e o 14\% do total do emprego na comunidade autónoma galega. Trátase dun plan de choque, vertebrado en nove bloques de execución, que destinará 11 millóns de euros á actividade turística e 10,6 millóns ao sector cultural, reforzados con 5,1 millóns de euros máis reservados a outras actividades enmarcadas no Xacobeo 2021, que inciden de xeito transversal en ambos os sectores. Precisamente, a celebración do Ano Santo foi considerada polo titular do Executivo galego como unha importante ferramenta de estímulo da actividade e do consumo que servirá de pulo para as industrias cultural e turística. Con esta finalidade, a Xunta de Galicia prevé levar a cabo un novo deseño do Xacobeo 2021, distinto ao previsto antes da crise da COVID-19, para darlles prioridade ás iniciativas de impulso económico e de activación do consumo e do emprego.

\section{Diagnose do sector da música popular a través dos representantes das asociacións profesionais e gremiais}

Neste apartado expóñense os resultados dunha serie de entrevistas feitas entre o 7 e o 16 de abril de 2020 a representantes das asociacións profesionais e gremiais da música popular. Para a elaboración destas entrevistas estruturouse un guión que recollía cuestións de interese claves sobre o eido profesional da persoa entrevistada, a modo de guía de contido de cara a favorecer o diálogo cos axentes seleccionados, con preguntas abertas que invitan ás persoas entrevistadas a manifestar a súa opinión e análise particular da situación e a expresarse con absoluta liberdade.

A través do cuestionario indagábase sobre a percepción da situación do sector da música en vivo antes da chegada da crise sanitaria e sobre o impacto da crise da COVID-19 na demanda e na actividade dos diferentes axentes que participan na cadea de produción. Tamén se pulsaba a súa opinión sobre que medidas debería tomar a Administración, sobre a incidencia do confinamento na poboación e os seus hábitos culturais, sobre as medidas de axuste que 
precisaban tomar as empresas ou as perspectivas de futuro para o sector, entre outras.

Para este particular solicitouse a colaboración de Joaquín Martínez Silva (Kin Martínez), presidente da Federación de la Música de España, Esmúsica; Manuel Alonso, representante da Asociación Músicas ao Vivo e de Músicos ao Vivo Sociedade Cooperativa Galega; Patricia Hermida, vicepresidenta do Intenational Music Managers Forum; Alberto Grandío, presidente da Asociación Galega de Salas de Música ao Vivo (Clubtura); Jordi Lauren, membro directivo da Asociación Empresarial dos Festivais de Galicia e organizador do festival SonRías Baixas, e Manuel Ángel Fariña Negreira, presidente da Asociación Galega de Orquestras (AGO).

\section{A dimensión industrial da música}

Para Joaquín Martínez Silva (Kin Martínez), presidente da Federación de la Música de España (Esmúsica) e director de Esmerarte, o sector da música leva en situación de precariedade dende sempre. É un sector sen regulación que o protexa ou que o defina especificamente en moitas áreas, como por exemplo na área laboral. No ámbito estatal non existe ningún tipo de convenio que conduza dalgún xeito ao desenvolvemento natural do sector, incluído sempre en epígrafes moi xenéricas que dificultan a difusión dos seus datos e o recoñecemento da súa actividade. Ás carencias de regulación laboral hai que engadirlles tamén a falta dun sistema educativo con formación pública regrada, dun marco fiscal de tributación adaptado á súa singularidade, así como a falta de recoñecemento da importancia dun sector que, cada vez que activa un produto ou evento, reactiva ao seu redor, de xeito indirecto, unha economía moi potente. Non hai que esquecer que a música se utiliza sempre como plataforma de visibilidade, pola súa gran forza comunicativa e de difusión. Non se pode imaxinar unha vida sen música, xa que se trata dunha disciplina que ademais está implícita noutras moitas actividades culturais como o cine, a publicidade etc.

A situación actual é dramática, advirte Kin Martínez, xa que esta crise vén a agravar unha situación de precariedade xa existente e, se non se toman as medidas necesarias, o sector desaparece dunha maneira rápida e drástica. A crise da COVID-19 precipita a necesidade de contar cun plan estratéxico. Urxe reconstruír o sector, protexer o seu contido e deseñar un plan de desenvolvemento de talento (introducir o talento no mercado e consolidalo). Os recursos humanos están mal xestionados porque existe precariedade no eido 
da música e, polo tanto, en toda a cadea e isto xa sucedía con anterioridade á crise de 2008.

Co fin de intentar mellorar este escenario, a partir de 2016 creouse unha mesa de traballo na que participaron os principais axentes que estruturan o sector da música en España, dende compañías fonográficas, tanto multinacionais como independentes, compañías musicais, editoriais, sociedades de xestión, intérpretes executantes, ata managers, salas de concertos e promotores. Sería o xerme do nacemento de Esmúsica en 2019.

Esta mesa de traballo tiña como obxectivo impulsar o sector da música mediante a mellora do seu sistema laboral, educativo, tributario, estratéxico e industrial, así como protexer o contido e os creadores e colaborar con el na xestión das súas carreiras. Para acadar estes propósitos desenvolveuse un plan estratéxico do sector durante tres anos, proceso que durou ata xaneiro de 2020 e que foi presentado ao Goberno central. Este plan foi moi aplaudido e moi benvido porque está pensado dende o sector e para o sector e se trata dun traballo minucioso que tiña que levar á creación este mesmo ano da Academia de Música de España, pero a chegada da crise sanitaria paralizou o proceso.

Aínda así, unha crise tamén pode ofrece unha oportunidade de cambio porque, se ben é certo que a música non estaba en crise permanente, a precariedade sempre existiu. Hai que aproveitar esta situación crítica para dar visibilidade a cuestións que nunca estiveron na axenda de ningún partido político. Considera que agora é o momento de traballar para establecer un plan de forza co fin de poder fortalecer o contido e a xestión do sector da música, como elemento dinamizador doutros moitos sectores. Este plan debería constituírse en tres fases:

- Un plan de rescate.

- Un plan de recuperación posterior ao plan de rescate.

- Un plan de desenvolvemento estratéxico, que sería coma un gran pacto de todo o sector da música, non só a nivel estatal senón que tamén poida ter conexións internacionais, especialmente en Latinoamérica.

Neste senso, a Federación formulou varios tipos de medidas. Hai que ter en conta que a representatividade de Esmúsica é moi significativa, xa que está integrada por máis de 111.000 socios que conforman todo un abano tipolóxico de actividades e que abrangue a totalidade do mundo da música. 
Entre as medidas propostas, en primeiro lugar atópanse as de carácter regulatorio, é dicir, as que non supoñen un custo económico, pero que son fundamentais, como por exemplo a definición de prazos. Se outros tipos de actividades como o fútbol xa teñen unhas perspectivas temporais máis ou menos definidas, para ter un plan de recuperación a industria musical tamén debe ter ese horizonte temporal.

En segundo lugar, é moi importante a declaración de forza maior, explica o presidente de Esmúsica. As e os promotores non poden cancelar os eventos de xeito unilateral, porque se enfrontarían a moitos problemas de tipo administrativo. A actividade desenvólvese en espazos públicos, os contratos que existen coa Administración, con axencias internacionais de artistas, incluso cos propios clientes etc. implican unhas obrigas e uns dereitos. Por mor do estado de alarma está prohibido celebrar eventos multitudinarios e, polo tanto, se se cancela de xeito unilateral calquera actividade, existe a obriga de cubrir todos os custos desas cancelacións. Esta situación resolveríase coa declaración de forza maior por parte do Estado, xa que eximiría ao sector desa responsabilidade.

En terceiro lugar, a industria solícitalles ás autoridades a flexibilización da devolución legal das entradas e que se faciliten ferramentas para regular esta cuestión. Cómpre aprobar a extensión dos prazos de reembolso, porque en moitos casos as entradas adquiren dereitos de retribución, como por exemplo o IVE, que xa foron ingresados en Facenda polas empresas, as cales perderían liquidez se teñen a obriga de efectuar a súa devolución.

En cuarto lugar, son fundamentais as medidas de protección dos recursos humanos. Como sinala Kin Martínez, non hai unha formación regrada pública e, como consecuencia, non se conta cunha bolsa de traballo. Se non se define un plan de formación específico que protexa eses recursos humanos, estes diluiranse noutros sectores produtivos e a recuperación non será posible.

A gravidade da situación constátase tamén nos datos de facturación, segundo expón Kin Martínez. A facturación directa da música desde febreiro ata decembro case chega aos 1.000 millóns de euros. Se desaparece esa facturación tamén desaparecen os 6.900 millóns de euros de impacto indirecto que produce na economía española. Cómpre ter en conta tamén que hai sectores dentro da música como autores, editores etc. cuxos ingresos son o pagamento dun traballo feito hai tempo (seis meses, un ano ou dous anos). Ante unha parálise total como a actual, este tipo de sectores vai ter un problema a longo prazo, a súa crise vai repercutir con máis forza dentro de seis meses ou un ano. 
Ante as ameazas ás que vai ter que facer fronte o sector, a Federación Esmúsica presentou ante o Ministerio de Cultura e Deporte un informe da situación. A música nunca contou cun interlocutor claro dentro da Administración. Este Goberno en pouco tempo ten que se enfrontar a un sector descoñecido ata agora e saber cal é a súa casuística. Os profesionais son conscientes, recoñece o presidente de Esmúsica, de que tomar decisións sen ter coñecementos sobre o eido da música é moi complicado e aplauden que o Goberno español non mire cara a outro lado. O concepto da industria musical apareceu por primeira vez no último Real decreto. A música debería ter un tratamento especial, pero ningún goberno de ningún color político lle prestou atención á situación de precariedade que está a vivir dende hai tempo. Algunhas das medidas económicas que se puxeron en marcha son positivas, como o incremento de 14 millóns de euros no orzamento do INAEM para axudar as estruturas das empresas musicais. Son medidas de protección e rescate ao sector de forma específica, ao igual que se ampliou a norma de desemprego para os profesionais, o financiamento a través dos plans ICO, os ERTE ou as sociedades de garantía recíproca, entre outras, que permiten ás empresas financiarse dalgún xeito.

Con relación á reacción da Administración autonómica, a Xunta de Galicia reuniuse dende o primeiro momento practicamente con cada unha das empresas do sector, cun comportamento exemplar, sinala Kin Martínez, algo que nunca sucedera ata agora, e cunha actitude máis positiva ca a do Goberno central, tanto no que se refire á atención e a escoita, como ao procesamento de medidas e traballo en conxunto. Esta actitude pode estar motivada tamén polo feito de que moitos profesionais do Goberno galego pouco afíns ao mundo da música, ao observar os estudos realizados nos últimos anos polo propio sector sobre o seu impacto económico, decatáronse do gran beneficio que reporta.

É moi difícil escoitar as peticións de todos os sectores, pero o Goberno galego si que escoitou ao sector da música e puxo ferramentas enriba da mesa que teñen que ver con solucións efectivas aos problemas reais. Fóronse creando distintas liñas consensuadas cos axentes para protexer toda a cadea de valor, para non deixar caer o sector nun momento moi importante para Galicia, ás portas da celebración do Xacobeo 2021.

Segundo o presidente de ESmúsica, as medidas anunciadas e promovidas dende a Xunta de Galicia, aínda que non satisfán a totalidade das peticións do sector, constitúen unha boa base, pendente soamente da súa adaptación normativa. O Goberno galego xa comprometeu as partidas orzamentarias para este exercicio, 27,7 millóns de euros para cultura e turismo. Non se trata de ferramentas financeiras senón de medidas de aplicación 
DOCUMENTOS DE TRABALLO CCG

inmediata, a través das cales se protexe a músicos, salas, fonográficas, promotores e profesionais. Estas medidas permitiranlles aos axentes da música traballar na creación e desenvolvemento de proxectos de cara ao Xacobeo e dan cobertura a unha parte importante das necesidades do sector.

A celebración do Ano Santo constitúe, sen dúbida, unha oportunidade de reactivación e un factor estimulante para Galicia nun ano moi delicado, indica Kin Martínez. A comunidade galega conta cunha oportunidade no tempo e xera unha expectativa especial como destino final do Camiño de Santiago. Con todo, este Xacobeo en concreto debería ser diferente e habería que dirixilo fundamentalmente cara aos valores humanos, vinculalo de xeito especial á realidade actual e que abranga temáticas ou cuestións que se viron afectadas pola crise e das que, dalgún xeito, se nos despoxou como a sustentabilidade, a igualdade, a accesibilidade ou a liberdade de expresión, entre outras. É necesario dotar dunha nova conceptualización ao Xacobeo, que sirva para exemplificar eses valores e que a música estea presente como un factor de cohesión social. Na volta á normalidade deberíanse asumir eses compoñentes como parte da identidade, creando en Galicia un espazo de reflexión e pensamento, como final do camiño dunha Europa que se creba despois desta crise global, pero tamén dende o que emerxa un novo principio, dotado de grandeza espiritual. Cómpre converter a Galicia nun punto de inflexión, nese lugar no mundo no que se reflexione cara a onde se dirixe o futuro da humanidade, un novo concepto que pode situar á comunidade galega nun gran foco a nivel mundial.

Nestes momentos tan delicados é posible que haxa que esquecer os grandes nomes do panorama musical mundial e traballar para fortalecer $\mathrm{o}$ tecido profesional da música, dos seus contidos, para elaborar un plan de activación e unha campaña de promoción aproveitando a oportunidade que brinda a celebración do Xacobeo. A música pode alzarse como un activo, potenciando o seu valor de comunicación, de marketing, de visualización etc. dentro dunha filosofía conceptual nova.

É incuestionable que a realización de eventos musicais, dentro ou fóra do marco da celebración do Xacobeo, son un reclamo tamén para o turismo e por iso tamén é importante a colaboración proactiva con este sector, co fin de ser suficientemente atractivos a todos os niveis. Ademais, hai que puntualizar que haberá determinados eventos que non se poderán levar a cabo ante a ausencia dun protocolo que seguir, dado que cómpre extremar o coidado tanto no que respecta á protección sanitaria como á responsabilidade do comportamento social. As empresas musicais durante esta época deberían, polo tanto, traballar na creatividade, desenvolver proxectos que non precisen 
dunha gran masificación de xente. Tendo en conta que o Xacobeo está ás portas, o tecido musical galego podería empezar xa a definir unha folla de ruta, tomar as decisións axeitadas e deseñar proxectos de cara ao futuro coa axuda de anticipos económicos e de axudas proactivas que lles acheguen liquidez ás empresas para entrar nunha fase de recuperación. Deste xeito xa non se consumirían recursos senón que se contribuiría ao impulso económico do sector.

Por sorte, segundo menciona Kin Martínez, o sector leva moitos anos traballando de xeito conceptual e pragmático nunha liña precisa de actuacións e, por primeira vez, semella que a música en España pode empezar a ser valorada. Dá a sensación de que os gobernos empezan a entender a importancia do sector musical, a reforzar o seu recoñecemento social, económico e cultural, tanto no ámbito galego e estatal como internacional, sobre todo no mercado iberoamericano, a través da Secretaría Xeral de Estados Iberoamericanos. Todo isto pode conformar o xerme dun cambio moi relevante e positivo para a música.

\section{Os/as músicos/as}

A asociación de Músicas ao vivo, a través da súa cooperativa (Músicos ao Vivo Sociedade Cooperativa Galega) creada en 2008 traballa dende hai dous anos no apoio aos profesionais da música, co fin de asesorar en cuestións relacionadas coa facturación dos seus concertos, informar sobre a lexislación vixente e amparalos para conseguir que poidan actuar cun contrato laboral como traballadores/as por conta allea, o obxectivo fundamental da cooperativa.

Segundo Manuel Alonso, membro directivo da asociación, este ano 2020 está practicamente perdido para o sector da música ou polo menos preséntase moi complicado, aínda que hai moita incerteza sobre as medidas que se van tomar nos próximos meses. É obvio que a paralización das actuacións da música en vivo está a abocar a unha situación límite aos seus profesionais porque precisamente son os concertos ao vivo os que manteñen o traballo dos músicos en directo. Na actualidade, para a práctica totalidade dos profesionais a meirande parte dos seus ingresos proveñen desas actuacións, mentres que o relativo á produción discográfica, os dereitos das plataformas dixitais etc. constitúe unha parte moi pequena, incluso os $\mathrm{CD}$ case se converteron máis nun produto de presentación e comunicación que nun negocio en si mesmo.

Para acadar unha maior repercusión nas demandas dos músicos, comenta Manuel Alonso, a asociación está a colaborar con outras plataforma estatais, o que permite mellorar o diálogo co Ministerio de Cultura e Deporte. 
Unha das cuestións que se comparten con estas plataformas ten que ver coa análise das cifras xeradas polo sector. Para ter un cálculo rigoroso da repercusión da crise da COVID-19, realizouse unha comparativa entre a facturación dos socios o pasado ano 2019 respecto á deste ano 2020. Hai que ter en conta, subliña Alonso, que no mes de marzo, cando se produciron as cancelacións dos concertos pola declaración do estado de alarma, xa había actuacións pechadas, contratos feitos e calendarios fixados, e polo momento non existe a seguridade de se será factible reabrir as salas de música e reprogramar as actuacións suspendidas.

A cooperativa Músicos ao Vivo SCG está composta por uns 300 músicos. A estimación que se realizou sitúa o volume de facturación entre marzo e agosto de 2019 en 280.000 euros. Estas son cifras brutas, pero non son únicas e exclusivas dos traballos realizados para a cooperativa, senón que os socios tamén son contratados por outras empresas, produtoras, artistas, autónomos etc. En 2020, dende marzo ata o día de hoxe a cancelación de actuacións foi practicamente total na cooperativa, reducíndose a actividade a algunha gravación esporádica ou algún concerto en liña.

Dende hai tempo, explica Alonso, a asociación centrou a actividade na loita contra a precarización existente no sector musical, unha situación que non se dá coa mesma gravidade noutros sectores culturais que contan cunha mellor regularización. En cambio, no eido musical hai unha porcentaxe moi elevada de traballos na economía mergullada e moitas das fórmulas que se utilizan para realizar eses traballos non se adecúan á legalidade. Por un lado, hai unha falta de cumprimento das normativas vixentes, a actividade dos músicos está rexida polo Real decreto 1435/1985, que regula a relación laboral especial dos artistas en espazos públicos, pero esta normativa non se adecúa á realidade actual e o seu incumprimento é xeneralizado dende hai moito tempo. A chamada industria musical está caracterizada por unha atomización empresarial e por unha precarización laboral que linda ás veces coa explotación, expón Manuel Alonso, unha situación na que todos teñen parte de culpa: os promotores, por non cumprir a legalidade, e tamén os músicos, un colectivo ao que lle custa moito estar unido e pensar no ben común.

Dende Músicas ao Vivo percíbense diferentes sensibilidades entre as distintas administracións públicas, un feito motivado pola delimitación dos ámbitos competenciais, xa que non poden esixir determinadas cuestións a unha Administración local ou autonómica, cando a súa influencia depende da competencia da Administración central. Valoran positivamente a actitude do Goberno estatal no que respecta ao recoñecemento da intermitencia do traballo do sector cultural, xa que é a primeira vez que se constata esta 
DOCUMENTOS DE TRABALLO CCG

situación de xeito legalizado -aínda que se recollía en parte no Real decreto-lei 26/2018, no que se aprobaron as medidas de urxencia sobre a creación artística e a cinematografía, e polo que puxeron e marcha actuacións para o desenvolvemento do Estatuto do Artista-. É un paso moi importante pero quedan moitas eivas e problemáticas por aclarar. Por exemplo, as axudas de prestación para os artistas obrigan aos profesionais a contar con 20 días mínimo de alta na Seguridade Social e tan só un $10 \%$ se pode acoller a ese tipo de axudas, porque a realidade é que teñen enormes dificultades para facer esas 20 altas. Se non se corrixen certas problemáticas por parte do Ministerio, moitos músicos e músicas poden quedar fóra das medidas de protección, ademais de sectores moi importantes dentro do eido musical como os técnicos, por exemplo. Xustamente, por este tipo de cuestións, matiza Alonso, se están a solicitar algunhas aclaracións ao Goberno a través das asociacións estatais das que forman parte e por isto tamén participan no paquete das 52 medidas presentadas ante o Goberno ${ }^{10}$.

No ámbito autonómico, a Xunta de Galicia presentou o plan de reactivación, pero os membros de Músicas ao Vivo cren que se afasta un pouco da realidade do sector para centrarse en exceso na vertente industrial, deixando fóra a cultura amadora e as realidades dos axentes máis pequenos. Cren que se debe ter en conta a todos os actores do sector, e que non se debe filtrar toda problemática a través de códigos económicos ou industriais.

Tamén pensan que se lle está a dar demasiada importancia ao Xacobeo, ao introducir neste a maior parte das medidas de protección. É conveniente mudar a tendencia de mesturar cultura e turismo xa que, en moitos casos, se lle dá preponderancia ao turismo sobre a cultura. Semella que hai interese por parte da Administración autonómica, pero non se sabe moi ben como se van levar a cabo as medidas presentadas. Hai partidas que, na súa maior parte, son reasignacións de programas xa previstos e, polo tanto, non hai moitas medidas novas.

A meirande parte do sector industrial da música estase acollendo aos ERTE e préstamos tanto do ICO como do IGAPE. Tamén as empresas pequenas, sobre todo para intentar financiar os custos mínimos das estruturas, os gastos correntes etc. Ademais, aqueles profesionais que estaban a alternar outras actividades laborais coa estritamente cultural tamén están a sufrir ERTE nos seus postos de traballo habituais, unha situación moi grave que se estende ata

\footnotetext{
${ }^{10}$ VV. AA.: 52 Medidas Extraordinarias para el Sector de las Artes Escénicas y la Música, op. cit.
} 
DOCUMENTOS DE TRABALLO os propios autónomos, que en moitos casos tiveron que deixar de pagar a súa cotización.

Esta crise está a afectar a todas as tipoloxías de empresas e suxeitos da actividade cultural, tanto empresas, como profesionais, como a cultura amadora. A plataforma Músicas ao Vivo centra especialmente a súa actividade nos máis precarios, porque considera que hai que aproveitar esta ocasión para concienciar a todos os axentes do sector da importancia das cuestións máis básicas que, no eido da música, están moi afastadas da normalidade doutros sectores. É fundamental, por exemplo, que as e os profesionais estean dados de alta na Seguridade Social cando van realizar unha actuación porque hai unha gran porcentaxe de actividades que se están a realizar de xeito irregular, fóra das redes institucionais e dos grandes eventos. Estes profesionais, os máis precarios, son os que o van pasar peor, xa que non se van poder acoller a ningunha das liñas de axudas, nin aos préstamos dispostos para os traballos culturais. Enfróntanse a unha situación de moita gravidade e vense abocados unicamente ás axudas por renda básica. Tamén o van pasar mal as empresas grandes polo propio peso da súa infraestrutura, e igualmente se resentirán todos aqueles que realizaron investimentos moi altos de cara á celebración do Xacobeo 2021.

A crise actual chegou de súpeto e, polo tanto, é diferente á crise de 2008, que foi moi dura pero progresiva. Por iso, pensan que xustamente este é o momento de repensar as estratexias, formular a cultura dende o contacto coa cidadanía, coa cultura de base. Cómpre que todas as administracións, tanto de ámbito local, como autonómico ou estatal, aposten pola cultura propia, pola cultura de base e fuxan un pouco de plans de políticas megalómanas, que apostan máis pola cultura foránea como espectáculo que polo reforzamento da cultura local e do acceso da cidadanía á cultura de base.

É certo que nos primeiros momentos desta crise si que houbo unha morea de mostras en liña totalmente gratuítas por parte dos artistas, que mostraron a súa arte a través das redes sociais de xeito totalmente desinteresado. Daquela pensaban que era un bo momento para facelo, pero agora cómpre poñer un pouco de orde e facer fincapé en que o traballo dos músicos é unha profesión e trasladar ese concepto tanto ao público como á cidadanía en xeral. Estanse a ver moitas iniciativas e campañas de diferentes administracións, sobre todo locais, como \#nonmecanceles, que reivindican solucións para que non quede ningún evento sen programar de novo. Pero, sobre todo, é fundamental desligar a reconversión da cultura musical nun produto turístico e propagandístico para que se converta nun ben cultural. 
DOCUMENTOS DE TRABALLO

É necesario sentar as bases dunha nova realidade, afondar na profesionalización, na formación, nas boas prácticas no sector, apostar por unha xestión despolitizada e coordinada e tamén coincidir na metodoloxía do xeito de proceder e para iso é fundamental a unión dos músicos. Neste sentido, a participación en plataformas de ámbito estatal é moi activa. A raíz da crise da COVID-19 e co obxectivo de exercer máis presión antes as diferentes administracións e entidades sociais e empresarias, creouse a Unión de Músicos Profesionais, da que tamén forma parte Músicas ao Vivo. Está constituída por 12 asociacións sindicais e profesionais de músicos que representan a máis de 7.500 artistas e autores de todo o Estado. Trátase dunha plataforma forte e nova mediante a que se reivindican os dereitos dos músicos única e exclusivamente dende a óptica dos músicos e músicas.

Respecto ás oportunidades que pode ofrecer a celebración do Xacobeo 21, son escépticos xa de por si coa propia natureza do evento pola intención implícita de intentar ligar a maior parte do peso da actividade cultural a esta celebración. Consideran que a cultura galega debe entenderse como un peso específico dentro do propio país, sen ter que asignala a ningunha clase de evento como o Xacobeo. Conscientes de que a Administración galega está a facer un esforzo para conseguir que esta celebración se converta nunha plataforma de visibilización e de atracción turística fundamental para Galicia, a plataforma Músicas ao Vivo formuloulles e comunicoulles ás administracións e ao propio conselleiro de Cultura e Turismo que hai que facer unha reconversión, agora máis que nunca, dese Xacobeo grandilocuente e megalómano, que estaba en principio previsto para o 2021, e convertelo nun Xacobeo que aposte pola cultura galega e por todos os seus sectores, tanto técnicos, como humanos, artísticos etc.

Neste sentido, a Xunta de Galicia comprometeuse a realizar esa reconversión, cunha visión galega, utilizando medios de produción e talento de Galicia. Ademais, as propias limitacións que impón a crise sanitaria van influír, xa que dificultará contratar artistas internacionais de gran renome, que supoñen un gran desembolso económico para Galicia. Hai que aproveitar a ocasión para fortalecer e fomentar a cultura galega. A celebración do Xacobeo pode constituír unha axuda importante a medio e longo prazo para o sector, en función da estratexia que se leve a cabo no que queda deste ano e, sobre todo, no próximo 2021, se o orzamento destinado ao Xacobeo se dirixe para poñer en valor a cultura galega.

En definitiva, a situación actual é complexa. Dende Músicas ao Vivo sempre se defendeu a realización de actuacións de música ao vivo, xa que ese é o eixe principal da historia desta asociación e reivindican que se continúen 
facendo. Entenden que esta crise non vai acabar coa música en directo, unha vez que remate o perigo da pandemia. É posible que haxa que reorganizar a tipoloxía dos eventos que se poderán celebrar e garantir o acceso da cidadanía á cultura. Por iso solicítanlles a todas as administracións que fagan un esforzo nese sentido, xa que precisan un modelo de sustentabilidade, de redistribución, de re-colocación dos recursos culturais no que a cidadanía sexa a protagonista xunto coa cultura local e de base, sen esquecer que a cultura é máis que un ben de consumo.

\section{Representación de artistas}

Patricia Hermida, membro do International Music Managers Forum, considera que o ámbito cultural sufriu a crise económica de 2008 con maior gravidade que outros sectores, en parte porque a cultura nunca tivo o recoñecemento que merece. Ademais, dentro do sector cultural, a música popular ocupa o último posto, xa que o apoio económico que lle outorga o Ministerio de Cultura e Deporte é moi escaso e cínguese case exclusivamente ao chamado circuíto de concertos "girando por salas”. Esta iniciativa consiste en dotar dunha serie de ferramentas de impulso a aqueles grupos que están a comezar unha carreira artística a través da creación e promoción dun circuíto de salas de concertos de toda España. É obvio, polo tanto, que a música popular parte dunha situación de desvantaxe respecto a outras disciplinas artísticas.

Neste momento, entende Patricia que ou se fai unha reformulación das políticas públicas de programación ou as empresas privadas non van ser capaces de afrontar un plan sectorial para seguir traballando. Dentro dun contexto de crise como o presente, a cultura sempre se considera algo prescindible e os investimentos públicos recaen noutros sectores prioritarios.

Desde hai uns anos as políticas culturais que se levan aplicado tendían cara á gratuidade total da cultura, ao consumo inmediato de todo o que cada un desexe, a chamada "cultura lixo", feito que non favorece en nada a reconstrución. Vai ter que haber unha reformulación moi drástica en termos económicos, polo que habería que comezar a valorar a posibilidade de establecer unha política de prezos, aínda que sexan simbólicos, para a cultura, que axude a construír unha industria co obxectivo de que, se nun futuro se volve repetir unha situación de crise como esta, se poida saír adiante sen tantos atrancos.

Como exemplo, Patricia Hermida expón o sucedido en Reino Unido, onde a MTV, que é unha empresa privada, lanzou unha campaña de micromecenado para as salas de concertos do país, ao decatarse de que estas 
DOCUMENTOS DE TRABALLO CCG son precisamente as grandes perdedoras nesta crise. Como resultado desta campaña conseguiron recadar 25 millóns de libras en poucos días, accións que en España xamais se levarían a cabo, pola falta de recoñecemento profesional dos músicos. Isto que acontece noutros países débese principalmente ao prestixio e recoñecemento que teñen os programadores culturais, tanto que sexan públicos como privados. Os programadores dunha sala ou dun teatro teñen que demostrar que os programas que propoñen son rendibles pola súa calidade e son eles os que teñen que gañar ao público polo prestixio que demostran nas súas traxectorias profesionais. En España esa figura de programador cultural profesional non existe e habitualmente son os concellos ou outras administracións as que contratan os programadores culturais, que ademais poden cambiar con frecuencia.

Esta situación de falta de recoñecemento profesional dos programadores culturais non varía moito no conxunto do territorio español. Porén, si é certo que ás veces a organización e programación de determinados festivais con certa traxectoria se confía ao mesmo programador, como é o caso de "Mar de Músicas”, dedicado cada ano á música e á cultura dun país diferente e programado polo Concello de Murcia. Polo tanto, si é posible algunha excepción con algún festival que teña unha liña de continuidade, un programa e un proxecto detrás, cunhas intencións culturais e unha proxección cara ao público. Pero o habitual é que os teatros funcionen como as salas, que simplemente se limitan a cobrar o alugueiro aos programadores e estes poden levar calquera contido sen ningún tipo de liña de programación.

Patricia Hermida, que exerce de avogada especialista en propiedade intelectual, tamén ofrece a súa opinión con respecto aos concertos gratuítos que se están a ofrecer por Internet e que certos músicos ou grupos musicais fan dun xeito completamente altruísta, como un xesto de apoio á poboación que se atopa confinada e que, polo tanto, lle serve como entretemento para soportar mellor esta situación de illamento social. Durante este tempo estivo a recibir consultas sobre este tema por parte dos seus compañeiros de profesión e considera que, por unha banda, isto é un indicador moi positivo de que a cultura importa xa que nunca houbo unha manifestación tan clara por parte da poboación de que é necesario o consumo de cultura. Pero, por outra banda, a parte negativa vén dada polo feito de que non se están ofrecendo contidos cun mínimo criterio de calidade. As e os artistas son conscientes diso pero estano facendo igual porque pensan que este é o momento de mostrar solidariedade e de estar coa xente, aínda que non se estean a respectar eses mínimos. Pero, ademais, a retransmisión de concertos por streaming é unha cuestión que, tanto en España como no resto do mundo, aínda ten moitas lagoas legais e, 
polo tanto, sen querer, estanse vulnerando dereitos dos artistas e estanse incumprindo moitos contratos que eses artistas teñen asinados con discográficas, editoriais etc.

Porén, sinala Patricia, un streaming ben canalizado, cunha asesoría xurídica clara, pode ser unha vía temporal para non perder algúns dos contratos que xa están asinados coas administracións públicas, que teñen uns gastos consignados e que podería axudar, en certo modo, a inxectar algo de capital aos grupos e ás compañías. Cómpre que as administracións manteñan estes contratos, sempre tendo en conta a situación en que estamos e segundo se vaian desenvolvendo as circunstancias. Estes concertos poderíanse reconducir por medio de streaming, aínda que sexa delimitado xeograficamente a unha comarca ou ao concello onde se vaia desenvolver o evento ou concerto, para que se lles pague o caché a eses grupos e que a cidadanía poida ver que tamén hai outra forma de facer as cousas. Pero insiste en que a retransmisión en streaming só pode ser considerada como unha solución temporal, porque os concertos en directo nunca poden ser substituídos por ningunha tecnoloxía.

Outra cuestión salientable refírese á resposta das administracións públicas ás demandas manifestadas polo sector ás autoridades competentes en todos os ámbitos: local, autonómico e estatal. As asociacións profesionais tiveron contactos coas administracións autonómica e estatal. No eido da música, existen diferenzas porque os distintos axentes teñen problemas diferentes. Por exemplo, non son as mesmas necesidades as que pode ter un festival e as que pode ter un artista ou un autor que, ademais de non contar cun espazo onde mostrar as súas composicións tampouco ten ningún tipo de ingreso.

Aínda que se están a presentar medidas de carácter transversal que van afectar directamente á cultura, como medidas fiscais, de tipos impositivos ou laborais, Patricia Hermida cre que se necesita traballar en prol de fomentar o tecido produtivo para dotalo de ferramentas e seguir traballando en propostas tanxibles e que estean dirixidas por persoas expertas no sector. Considera que é máis útil facilitar mecanismos como, por exemplo, a creación de proxectos de colaboración nos que as empresas estean obrigadas a traballar conxuntamente, a dotación de fondos para a creación dos artistas ou unha focalización obrigatoria da programación na contorna. Este tipo de accións permitiría asegurar a continuidade das empresas e crear un tecido viable, porque a inxección de capitais ao final se concentra nun número limitado de empresas que non están obrigadas a construír esta ponte cara á nova realidade.

Considera que no sector da música popular o que se demanda é unha liña de traballo para proxectos concretos, que permita seguir crecendo e 
DOCUMENTOS DE TRABALLO creando e que obrigatoriamente implique a todos os sectores, os músicos, os técnicos etc. Por exemplo, se se programou un concerto dentro dun circuíto como o de "Cultura no Camiño" e non se pode levar a cabo nun lugar determinado polas restricións de cabida, sería aconsellable poder facelo e retransmitilo por streaming para que toda a xente que estaba implicada na organización deste evento poida seguir traballando, non só os artistas, senón tamén as empresas de son, as de iluminación, de produción e todas as que están implicadas no tecido. Pero, en cambio, se simplemente se lle dá unha subvención ou un fondo de compensación a unha determinada empresa de técnicos de son, só resulta beneficiada esa empresa e non todas as que están arredor dun proxecto. Igualmente o risco é maior xa que só unha recibe esa axuda e se non logra remontar cando remate a crise o resultado é negativo para todos; non obstante, se se se apoia un traballo, ábrese unha liña de colaboración que pode dar oportunidade a moitas outras empresas dentro do sector cultural.

O futuro que Patricia Hermida prevé é moi complicado porque nestes momentos é moi difícil avaliar as medidas adoptadas polo Goberno central para a chamada "desescalada" co fin de saír da crise sanitaria. Considera que son medidas totalmente parciais e que propuxeron unhas cifras relativas ás capacidades das salas de concertos que non son viables en termos económicos. Xa non se trata só das cifras de persoas que se poidan meter nunha sala ou nun recinto ao aire libre, segundo a fase de "desescalada” definida polo Goberno, senón que hai que concretar en que condicións sanitarias se van poder realizar os concertos para poder manter a seguridade do público asistente, sobre quen van recaer os custos destas medidas e se vai haber algún tipo de apoio para poder afrontar ese sobrecusto na produción. Polo tanto, resulta totalmente imposible establecer un escenario de futuro neste momento.

Con referencia ao tipo de empresas que poderían sobrevivir mellor despois de que pase esta crise, Patricia Hermida pensa que todo depende da diversificación do modelo de negocio dunha empresa e de canto maior sexa a capacitación técnica e formación do seu persoal. Por exemplo, hai empresas que non se limitan só ao mundo da música e que abriron outras vías para o seu traballo, como a organización de congresos, entre outras. No caso dos grupos musicais, a única saída para algúns artistas é a compaxinación da súa actividade artística con outro tipo de traballo. En definitiva, explica Patricia, os artistas son os grandes prexudicados neste momentos por varios motivos:

En primeiro lugar, non teñen dereito a percibir prestacións por intermitencia nas altas na Seguridade Social. En segundo lugar, nunca se valorou o seu traballo, ao contrario do que pasou en países como Francia, onde teñen un estatuto que regula a actividade dos artistas, algo que en España 
comezou a elaborarse hai tempo pero que quedou paralizado en decembro de 2018 polo cambio de goberno e as sucesivas crises políticas. O Estatuto do Artista tiña como obxectivo recoñecer os seus dereitos como traballadores para percibir unha remuneración en tempos de crise como a que estamos a vivir, nos que se ven obrigados a paralizar a súa actividade laboral, pero seguen tendo que pagar impostos e outros gastos derivados do traballo que veñen realizando, como, por exemplo, a gravación dun disco. Por último, as e os artistas tampouco poden contar cos recintos previstos nun principio para realizar un concerto por mor das limitacións de cabida das salas ou mesmo pola propia seguridade do público, xa que non compensa economicamente.

Ademais, os problemas de fondo que xa viñan arrastrando de atrás e que foron obxecto de reivindicacións por parte do sector, como o aprazamento da débeda, a modificación das cotas da Seguridade Social, o imposto de Sociedades, do IVE, non teñen unha solución inmediata. Isto débese fundamentalmente a que son asuntos con casuísticas moi diferentes e, aínda que se propoña unha norma xeral para a totalidade dos artistas, iso non resolve todos e cada un dos problemas que poden xurdir. O que si se podería facer é inxectar unha serie de fondos económicos a través das sociedades de xestión, como a SGAE, e que estes repercutan directamente nos autores/as ou en axudas á creación.

Cabe ter algo de optimismo de cara a un futuro aínda que non está nada claro, comenta Patricia. Mentres que a Xunta de Galicia se puxo en contacto co sector desde o principio para interesarse polas súas demandas, o Ministerio de Cultura tivo nun primeiro momento unha actitude menos proactiva. Non se sabe, de todas as formas, que solucións pode achegar a Xunta, pero polo menos interesouse polos problemas de todo o sector, aínda que Hermida recoñece que vai resultar moi difícil atopar unha batería de medidas que contente a todos polas singularidades dos profesionais que conforman o sector.

Ademais da Administración autonómica, os concellos van ter que desempeñar un papel fundamental na dinamización do sector cultural, matiza Patricia Hermida, tanto no apoio ás salas como ás programacións culturais. Hai unha serie de partidas orzamentarias que hai que reestruturar fundamentalmente para tratar de solucionar a crise sanitaria. Pero o que deben facer as administracións locais é apostar por fomentar a cultura local en vez de cancelar todos os eventos culturais. É unha cuestión de vontade política, porque aínda que haxa que minguar os orzamentos para eventos culturais, si se poden organizar actividades que poñan en valor a cultura local e de proximidade. 
DOCUMENTOS DE TRABALLO CCG

Con relación á celebración do Xacobeo 2021, os orzamentos asignados este ano 2020 a grandes eventos que xa non se van poder celebrar deberíanse canalizar para fomentar eventos de menor custo pero que sirvan para apoiar o sector cultural. Patricia considera que o Xacobeo é unha boa oportunidade para apoiar ao sector cultural galego, porque non é en absoluto aceptable que as grandes empresas beneficiarias de investimentos públicos para grandes festivais, como os que se desenvolven ao abeiro do Xacobeo, recaian en empresas de fóra de Galicia. Se hai que reducir as pretensións artísticas dos festivais, agora é momento. De feito, unha das demandas nas que coinciden absolutamente todos os sectores dentro da cultura refírese ao feito de que, dadas as circunstancias actuais, nestes momentos non cabe a celebración dun Xacobeo que non sexa fundamentalmente galego en todos os sentidos, non só na programación. De todos os xeitos, non cre que a Administración autonómica logre acadar un compromiso total, pero si pensa que se vai facer un esforzo neste sentido. Por iso coida que non van deixar pasar unha oportunidade como esta de poder saldar a débeda histórica que teñen co sector e que só vai acontecer en Galicia.

Por outra banda, considera que a programación dos festivais non debe contrapoñer cultura e turismo, senón que máis ben debe inclinar a balanza cara á cultura, dado que nestes momentos os festivais están demasiado centrados no turismo como medio de reactivación económica, e mesmo están formulados como "centros comerciais de ocio", onde o máis importante é calquera outra cousa menos a música.

Polo tanto, di que é hora de reescribir o futuro, porque o que está claro é que mentres non exista unha solución sanitaria segura para toda a sociedade, os festivais non se van poder formular coas condicións en que se viñeron celebrando ata agora, nos que os recintos acollían a milleiros de persoas. De feito, a maior parte das xiras internacionais de todos os grupos están canceladas.

\section{As salas de concertos}

Na Asociación Galega de Salas de Música ao Vivo, Clubcultura, están representadas a maior parte das salas de concertos de Galicia, un total de 31, que realizan como mínimo 25 concertos ao ano. Clubtura pertence pola súa vez a ACCES, a Asociación Cultural Coordinadora Estatal de Salas, e a través dela a Live/DMA, a Asociación Europea de Salas de Concertos. Dende 2007, ano en que inauguran a súa actividade, estiveron asociadas máis de 60 salas, das cales case a metade cesaron a súa actividade. A maioría das salas de concertos en 
Galicia conta, polo xeral, cunha cabida de menos de 300 persoas, agás algunha excepción. A programación das salas supera os 100 concertos ao ano, con presenza en numerosas poboacións de Galicia, o que as converte no único medio de escoitar música en directo para moitas vilas pequenas.

A percepción de Alberto Grandío, presidente de Clubtura, sobre a situación actual é de preocupación, xa que as salas de música ao vivo arrastran unha realidade precaria dende sempre, o que se agudizou coa crise do 2008 e que semella que será aínda peor a raíz desta nova crise sanitaria. Hai que ter en conta que a actividade de salas de concertos onde se ofrece música ao vivo require moitos gastos e, en xeral, non contan cunha gran cabida para sufragalos. Polo tanto, pódese dicir que case sempre foi unha actividade deficitaria, movida principalmente polo voluntarismo e paixón dos promotores e que, en moitos casos, non ten como prioridade a rendibilidade económica. Ademais, as salas non contan con ningún tipo de axudas, agás para o circuíto de concertos da "Rede Galega de Música ao Vivo", promovido pola Axencia Galega das Industrias Culturais.

Dende hai xa máis de 30 anos, indica Grandío, as asociacións de músicos ao vivo e salas de concertos levan reivindicando que estas sexan consideradas espazos culturais e poidan optar a axudas específicas. As diferenzas en España son moi salientables en comparación con outros países, nos que o apoio económico é moi estimulante, con achegas que oscilan entre os 80.000 € e $100.000 €$ ao ano para a programación musical promovida por salas cunha cabida para 200 persoas, como a maioría das que se sitúan en Galicia.

A situación actual provocada pola pandemia tivo como consecuencia a anulación, ata o mes de xuño, de entre 30 e 40 concertos de grupos locais e foráneos, pola imposibilidade de reprogramar as datas. Un dos graves problemas das medidas de confinamento e restrición da mobilidade é que as salas non poden deseñar a programación da súa actividade e mentres seguen a soportar os gastos correntes de mantemento das súas estruturas, como é o caso dos alugueiros dos locais, que dependen da boa vontade dos propietarios e, en moitos casos, de negociacións para conseguir rebaixar o custo. No ámbito estatal, estase propoñendo que se deixe de pagar o alugueiro mentres estea pechada a sala e que se volva cobrar unha vez que se reabra. Segundo Grandío, a mellor opción sería a que se dá en Francia, onde aos donos de salas con problemas económicos se lles permite non cobrar os alugueiros e, a cambio, poden recibir axudas do Estado. En calquera caso, no sector son conscientes de que se trata dunha situación que afecta a todo tipo de negocios con local comercial. 
DOCUMENTOS DE TRABALLO CCG

A situación laboral das persoas que traballan neste sector tamén é delicada e moi variable e abrangue dende os traballadores autónomos ata as salas con cadros de persoal contratado. Tanto nun caso coma noutro, para facer fronte aos gastos fixos sen ingresos por actividade, os profesionais vense abocados a solicitar ou ben axudas directas do goberno, ou ben a realizar ERTE entre os seus empregados. Trátase dun sector que na súa maior parte carece de protección económica e que se caracteriza por vivir ao día, o que inflúe de xeito negativo no ánimo e nas perspectivas de cara ao futuro, tanto por parte das salas como dos propios músicos.

Entre as medidas que se poden ir aplicando nas diferentes fases da desescalada por mor da COVID-19, preocupan especialmente aquelas que teñen que ver coa redución da cabida das salas, posto que unha diminución desta a un $30 \%$ ou $50 \%$ dificulta a programación de determinados concertos e fai inviables de xeito particular a contratación de grupos de fóra de Galicia, a cuxos gastos por actuación se unen outros desembolsos, como o pagamento das estancias, manutencións, equipos de son etc. A isto hai que engadir as propias limitacións que se impoñen coas medidas de seguridade, como o uso de máscaras, distancias de seguridade de dous metros..., normas que son totalmente incompatibles co papel socializador inherente a este tipo de locais, onde non só se vai escoitar música, senón que tamén o público interactúa entre si. Cómpre, polo tanto, que as administracións se impliquen e doten dunha inxección económica directa ás salas, que, en caso contrario, se verán obrigadas a pechar.

Estas axudas económicas deberían ademais estenderse ata final do ano 2020, e non só cinguirse aos meses que dure o peche, principalmente porque de cara a este próximo verán non parece viable a programación de ningún concerto, e no caso de que se puidese reiniciar certa actividade despois do verán, as salas seguirían supeditadas á limitación da cabida, o que dificulta enormemente a súa sustentabilidade.

Nese sentido, o sector está a formular diferentes propostas como medidas de presión ante a Administración para que esta se sensibilice coa situación pero, polo momento, non hai respostas claras con compromisos firmes. Unha das posibilidades que propón o Goberno de España é a solicitude de créditos ICO, con xuros reducidos para as PEME con dificultades económicas, unha iniciativa que, para Grandío, non se adapta ás necesidades das salas de concertos, xa que os espazos están cerrados e non xerarán ingresos económicos durante meses.

Para o presidente da Asociación Galega de Salas de Música ao Vivo, a cultura en xeral sempre foi o eido máis feble porque tanto as administracións 
DOCUMENTOS DE TRABALLO CCG autonómicas como as nacionais non recoñecen a súa importancia e relegan o sector aos últimos postos cando se trata de axudas económicas, precisamente nun momento de gran fraxilidade social, no que o sector está a demostrar que a súa presenza é necesaria para a estimulación emocional e psicolóxica da sociedade. Aínda así, nos diferentes encontros que se mantiveron coa Xunta de Galicia, dende a asociación observaron boa vontade política e o Goberno galego comprometeuse a crear unha partida orzamentaria de 25 millóns de euros para distribuír entre os diferentes sectores culturais e para reprogramar todas as actividades previstas, ademais de pór á disposición dos axentes culturais o orzamento previsto para o Xacobeo. Con todo, despois da primeira reunión non se volveu ter contacto ningún coa Administración para concretar esas medidas e só se previu a creación dunha comisión de seguimento para tratar este tipo de cuestións, comisión que hoxe en día aínda non se reuniu. As administracións deben valorar a función cultural das salas de concertos e, de xeito especial, no ámbito local, no que terían que reforzar economicamente aos concellos, que, nestes momentos, non teñen capacidade resolutiva.

Unha achega moi importante está relacionada coas campañas nas que se ofrecen concertos gratuítos polas redes sociais. Considera que para moitos creadores estas iniciativas son como unha válvula de escape para poder soportar o confinamento. Pero entende que, para a xente que lle gusta escoitar música en directo, os concertos que ofrecen pola televisión e, sobre todo, por Internet non teñen unhas mínimas condicións de calidade. Apunta que, cando falan de retransmitir concertos en streaming, é sempre baixo unhas condicións de calidade, se non iguais, polo menos semellantes ás que podería ter o público en concertos de música en directo.

No que respecta a outras comunidades autónomas, nalgunhas están programando concertos en streaming financiados pola Administración. En Galicia esta asociación xa tivo contactos coa AGADIC para poder facer concertos en streaming, pero non se concretou nada sobre cantos concertos, como se van facer ou canto lles van pagar ás salas. Os representantes das salas piden que lles dean uns 400-500 £ por concerto a cada sala e que se fagan un mínimo de 5 concertos ao mes desde xa, mesmo sen público.

Unha das propostas que se formulan dende Clubcultura é a supresión por parte dos concellos dos gastos correntes, que constitúen un desembolso moi elevado para as salas, e suxire que os concellos non lles cobren os gastos de luz e auga, pero os concellos non se implican. Así, propón que, xa que algúns eventos que teñen un orzamento importante, como por exemplo o Arde Lucus, se suspenderon por mor da crise sanitaria, as administracións dediquen parte deste orzamento a apoiar a cultura de base. 
A asociación de salas está totalmente en contra da gratuidade no ámbito da cultura, porque o que non se paga non se valora. Polo tanto, é preferible que as salas poidan acceder a axudas directas dirixidas a espazos culturais, que facer concertos gratuítos. O que tampouco pretenden é ser un sector subvencionado, algo que, por outra parte, non é positivo para o propio sector.

Nese sentido, comenta que a Administración ten destinados moitos cartos para a celebración do Xacobeo pero que, dada a situación, é mellor repartilos e destinar parte á cultura. Por exemplo, no caso das salas de concertos, non entenderían que se pechasen por falta de axudas por parte da Administración e que, en cambio, se destinase moitísimo diñeiro a organizar macroconcertos. Polo tanto, propón que se destinen axudas a estas salas porque, á fin e ao cabo, son as que sempre estiveron loitando para que a cidadanía puidese ter acceso á música en directo, en moitos casos en poboacións pequenas, onde a xente non tería outra posibilidade de acudir a concertos. Polo tanto, considera que se a Administración non se implica en salvagardar as salas e, en definitiva, na cultura, estas non terán opción ningunha de sobrevivir.

DOCUMENTOS DE TRABALLO

\section{Os festivais}

Jordi Lauren, da Asociación Empresarial Festivais de Galicia, considera que nestes momentos resulta moi complexo facer unha avaliación da repercusión que pode ter a actual crise sanitaria no sector da música. Festivais de Galicia está a facer unha auditoría interna sobre como lle está a afectar ás empresas, pero non poden ofrecer datos porque na actualidade se descoñece os festivais que se van poder celebrar. A posibilidade de que se poidan realizar eventos ao aire libre cunha capacidade para 400 persoas e con determinadas características posibilitaría organizar concertos, pero en realidade con grande incerteza. O problema non é a cabida que poidan acoller os espazos, senón que non se coñecen os protocolos de medidas preventivas que hai que adoptar tanto para as e os traballadores como para o público. Por iso, pensa que non serve de nada programar eventos para espazos onde poidan acoller un público, sexa a cifra que sexa de espectadores, sen coñecer os custos que vai supor poñer en práctica as medidas preventivas e, polo tanto, non se poden facer orzamentos precisos.

Hai outro problema engadido que vén dado polo protocolo de seguridade que se teña que adoptar. Por unha banda, este tipo de protocolos son moi custosos e lentos e, pola outra, as medidas de seguridade poderían 
esixir que o público tivese que acceder ao recinto con moita antelación. Polo tanto, esta situación esíxelles moita precaución e non programar nin anunciar nada ata coñecer con exactitude as normas precisas que teñen que adoptar.

Estáselle demandado ao Estado, ao igual que se fixo noutros países, comenta Jordi Lauren, que estableza unha norma para que non se poida organizar ningún tipo de evento musical ata setembro. É certo que isto lles pode causar un enorme prexuízo, pero polo menos unha medida dese tipo pode marcar un horizonte temporal, e así poderían ter unha garantía xurídica á hora de cancelar concertos e establecer protocolos para reactivar a actividade das empresas, que hoxe en día é completamente imposible. Tamén reclaman que haxa unha lei o suficientemente flexible como para alongar o prazo de devolución de cartos das entradas e que non provoque o peche inevitable de empresas promotoras.

De feito, neste momento en España non están cancelados todos os festivais programados para os vindeiros meses. En Galicia, canceláronse todos os festivais máis recentes e, dos que están programados para os vindeiros, só se cancelaron (ou adiaron) "O Marisquiño" e o WOS e, nos últimos días, o "Son do Camiño", o "Portamérica” e o "Resurrection Fest”. Ademais, nos medios estase a publicar unha información nesgada que só contribúe a confundir ao público e, polo tanto, prexudica gravemente ás empresas promotoras dos festivais porque se dá unha imaxe de falta de transparencia que non é real, xa que a organización dos festivais está a facer un verdadeiro esforzo por poder comunicarlle a información da que poida dispor. O que non pode facer é cancelar de forma unilateral todos os contratos que ten firmados un promotor para levar a cabo un festival, porque necesita unha garantía xurídica e non ter que asumir a responsabilidade e os custos que lle poidan reclamar as empresas prexudicadas.

En canto á situación laboral do persoal das empresas promotoras, di que todos os traballadores e traballadoras están afectados por ERTE. Pero no sector da música, que é o último que se vai incorporar á actividade, os ERTE van ter que prolongarse ata moito máis alá do 30 de xuño, que é o que está establecido nestes momentos. Considera tamén que a Administración pública, especialmente a Administración local en concellos pequenos que carecen de gabinetes xurídicos, tamén necesita readaptarse de forma solvente a esta nova situación, porque os promotores teñen asinados contratos con artistas que teñen que manter.

No que respecta ás medidas económicas adoptadas, a gran maioría das empresas promotoras solicitaron préstamos a través do IGAPE, o cal pode resultar problemático polas circunstancias deste tipo de empresas. Para 
DOCUMENTOS DE TRABALLO

solicitar un préstamo, teñen que pedir un aval a SOGARPO (Sociedade de Garantía Recíproca da Pequena e Mediana Empresa. SOGARPO é unha entidade que ten como obxectivo facilitar o acceso ao financiamento das PEME e autónomos galegos, a través da concesión de avais e condicións vantaxosas en canto a tipos de xuro e prazos de amortización. No contexto da actual crise sanitaria o IGAPE sacou un liña de préstamos avalado por SOGARPO (Liña IGAPE COVID-19) dirixidos á práctica totalidade de sectores. As empresas beneficiarias poden destinar esta liña especial de préstamos avalados a un amplo abano de necesidades urxentes derivadas da actual situación de alarma pola pandemia da COVID-19. Así, posibilitaríalles financiar capital corrente sen límite para pagamentos a provedores, materias primas e aprovisionamentos, para pagamentos a acredores pola prestación de servizos, alugueiros e subministracións, para pagar nóminas e seguros sociais e para gastos financeiros operativos e primas de seguros que dean cobertura á actividade empresarial.

O problema que atopan as empresas promotoras de festivais á hora de solicitar estes créditos é que non son consideradas empresas solventes, dado que se este ano se cancela un festival promovido por unha empresa, esta pode estar case dous anos sen recibir ningún ingreso. Jordi Lauren reivindica que as empresas promotoras dos festivais son rendibles pero que, á hora de solicitar avais bancarios de organismos dependentes da Administración, teñen moitos problemas porque as súas actividades son consideradas de risco por carecer de estabilidade económica.

Ademais, a Administración leva xa traballando con este tipo de eventos como reclamo turístico porque teñen un grande impacto económico e social e de posta en valor do territorio, cunha repercusión moi importante no ámbito das comunicacións e que achega moitos recursos dos que non poden dispoñer as administracións. Neste sentido, pódese dicir que non existe outro sector que poida facer tanto como o dos festivais para poñer Galicia no mapa e que, polo tanto, teña tantas repercusións económicas directas no país. Así, cada euro investido pola Administración nun festival xera un retorno económico moi importante ${ }^{11}$. O sector dos festivais profesionais foi capaz de crear un contorno seguro, estable dunha maneira moi particular, cunha identidade propia moi evidente, moi afincado no territorio e enfocado cara á cultura galega.

No ámbito da Administración autonómica, tanto a Consellería de Cultura e Turismo como a AGADIC si entenden que os festivais de música son dinamizadores. Agora ben, estamos nunha situación tan extraordinaria a nivel

\footnotetext{
${ }^{11}$ Axencia Galega das Industrias Culturais (2018), op. cit.
} 
de recursos que consideran que non poden pretender que a AGADIC e a Consellería de Cultura salven as súas empresas porque, incluso dende un punto de vista social, non sería en absoluto entendible pola cidadanía. Pero o que si lles gustaría é que puidesen traballar en conxunto para deseñar algún tipo de ferramentas, xa non só de tipo económico, senón tamén xurídicas e estratéxicas que lles permitan facer unha pequena paréntese antes de que poidan volver desenvolver a súa actividade profesional.

O Xacobeo pode converterse nunha ferramenta para recuperar e revitalizar o tecido industrial de Galicia, sobre todo o turismo, pero tamén a cultura e outros sectores, de tal xeito que as empresas que están a traballar en Galicia o poidan seguir facendo para dinamizar o territorio.

De cara ao ano que vén, no que se celebra o Xacobeo, en principio teñen esperanza de poder organizar os festivais que este ano non poidan ter lugar, pero o problema é que tampouco hai ningunha garantía. Isto suscita unha gran dúbida sobre o traballo de planificación dos festivais. A isto hai que engadirlle que hai moitos sectores que dependen deles directa ou indirectamente, como a hostalaría, o turismo etc. e, se non se levan a cabo os festivais, tamén se desactivan estes sectores. As persoas afectadas estanlles demandando que non cancelen os festivais, pero a cuestión é que a cancelación dun festival está nestes momentos totalmente condicionada pola situación sanitaria e supeditada ás ordes do Goberno. Polo tanto, o sector pide que un equipo de técnicos poida aclarar todas as dúbidas que teñen nesta situación e acabar coas incertezas en que están inmersos.

Confian en que a Xunta apoie economicamente a estas empresas porque, aínda que son empresas estruturalmente pequenas e con poucos empregados, teñen capacidade para crear moitísimos postos de traballo. Por exemplo, un festival como "Son Rías Baixas” pode crear ata 300 empregos, que levan consigo moitas subcontratacións, o pagamento de impostos e un grande impacto económico, porque nun concello como Bueu, duns 12.000 habitantes, poden mobilizar ata 22.000 persoas en tres días, non só no na comarca do Morrazo, senón tamén na de Vigo e Pontevedra, e calcúlase que ten un impacto económico dun millón de euros, que inflúe economicamente en todos os sectores. De feito, só en Bueu o pico da facturación de todos os comercios prodúcese na fin de semana do festival e estes contratan máis persoal na semana en que se celebra o festival para poder dar resposta a toda a demanda que teñen. Por iso, os festivais xeran moita riqueza de forma indirecta. De todas as formas, recoñece que os promotores non son capaces por si sós de xerar tanta riqueza e, polo tanto, é necesario protexer a toda a estrutura sobre a que se asentan os festivais. 
DOCUMENTOS DE TRABALLO CCG

As empresas do sector da música investiron moito diñeiro en formar equipos técnicos de traballo especializados, que se atopan entre os máis competentes do Estado. Agora corren o risco de que todos eses profesionais ben formados, ao non poder traballar no sector da música porque está parado, se reconvertan para traballar noutros sectores como a construción ou a enxeñaría. Polo tanto, isto implica que marchan todos os profesionais cos que contan, o sector da música vai perder a competitividade que tiña a curto prazo.

As medidas que están a pedir á Administración nestes momentos para poder salvar o sector concrétanse fundamentalmente na carga de traballo, porque un dos grandes contratistas cos que poden contar neste momento é a propia Administración. Por iso reiteran a necesidade de que contraten os seus servizos para desenvolver e levar a cabo todo o plan estratéxico do Xacobeo que se está a reformular nestes momentos. $\mathrm{O}$ feito de que a Administración contrate a estas empresas para isto xa lles pode permitir manter todas as estruturas de traballo coas que contan e minimizar as perdas para que cando poidan volver reiniciar a súa actividade poidan sobrevivir. Considera vital que a Administración os escoite e conte con eles porque son empresas que teñen moita capacidade de reconverter e levar a cabo proxectos para adaptalos ás novas esixencias. A realidade esíxelles ser un sector moi creativo e intuitivo para poder afrontar os retos que se lles presentan. Polo tanto, á Administración non lles están a pedir subvencións a fondo perdido porque son conscientes de que nestes momentos hai necesidades moito máis urxentes ás que a Administración debe atender.

Mentres non se reinicien as actividades do sector musical, a única solución que ve viable para que estas empresas sobrevivan é a través do endebedamento, o cal minguará esa capacidade de endebedarse no futuro. De feito, este sector, polas súas propias características empresariais, ten que contar coa posibilidade de financiarse, xa que fai investimentos moi fortes e obtén retorno seis meses ou mesmo un ano despois. Polo tanto, a curto prazo non vai poder contar con esa ferramenta económica e van ser as propias empresas as que van ter que tomar decisións individualmente de acordo coa súa propia estratexia empresarial e aí a Administración non pode intervir. Por iso, as empresas están a ter en conta todas estas limitacións e, dentro do sector, son conscientes de que moitas non van poder sobrevivir.

De cara á organización dos grandes eventos do Xacobeo, coincide con outros axentes do sector en que se debe enfocar claramente cara ás empresas locais para que realmente se poidan ver beneficiadas. Se non acontecera a crise da COVID-19, o Xacobeo estaría claramente dirixido cara ao turismo internacional, porque xa se daba por feito que o turismo nacional xa estaba 
incluído dentro dos obxectivos propios do Xacobeo. Polo tanto, considera que nesta situación o que cómpre facer agora é redirixir de novo o obxectivo do Xacobeo cara ao turismo nacional e, indirectamente, a Portugal por estar dentro da Península Ibérica. Ademais, a Administración tamén ten que confiar nas empresas galegas, porque teñen moito talento e capacidade para poder afrontar este reto e realizar grandes proxectos. Considera que o que hai que facer é aproveitar o Xacobeo para potenciar os proxectos propios que levan funcionando en Galicia moitos anos, para que esas empresas galegas que tiñan cinco empregados poidan chegar a ampliar o seu cadro de persoas e desenvolver proxectos fóra de Galicia.

É importante fortalecer a industria cultural galega para poder exportala. A industria musical ten unha capacidade de exportación moi grande e hai moitos mercados nos que poden traballar e agora non o están facendo. Considera que, se as cosas se fan ben dentro do sector musical, as empresas poden saír reforzadas a medio prazo.

Estima que a profesionalidade do sector musical en España e en Galicia non está valorada coma noutros países, porque pensamos que o que vén de fóra sempre é mellor que o noso. Pero en cambio, fóra de Galicia hai determinados proxectos galegos que, no conxunto do territorio español, se consideran como modelos sobranceiros na industria musical de bo funcionamento e unión porque non requiren grandes investimentos públicos, están transmitindo unha marca consolidada dentro de Galicia e teñen unha formulación dun plan estratéxico de posta en valor.

En Galicia, o sector turístico entendeu perfectamente o valor de marca da industria musical galega, pero isto non acontece en todos os sectores. Fest Galicia é recoñecido como un destino turístico musical no conxunto de España, igual que pode ser recoñecido un recurso puramente turístico como as Rías Baixas. O caso de Fest Galicia, dentro do territorio español, só é comparable a outro que existe na Comunidade Valenciana, e é moi recoñecido dentro do sector pola súa boa praxe.

Como conclusión, Jordi Lauren cre que esta crise pode servir para salvar a industria musical se todos se unen cara a un mesmo obxectivo, tanto as empresas como as administracións. Cómpre que se formule un plan estratéxico para o sector e que sirva para fortalecelo, de tal xeito que despois desta crise e de cara a un futuro se salve un maior número posible de empresas. Recoñece que non é unha cuestión política, senón algo sobre o todos teñen que chegar a un acordo. 


\section{As orquestras}

Segundo Manuel Fariña, presidente da Asociación de Orquestras de Galicia (AGO), as orquestras son un sector moi arraigado en Galicia, cuxa actividade profesional é extremadamente estacionaria e que xa sufriu moito coa anterior crise económica. Galicia concentra o maior número de orquestras por comunidade autónoma de toda España. A crise sanitaria produciuse nun dos momentos máis vulnerables para este sector porque coincidiu xustamente co inicio da temporada alta para as orquestras, o momento en que teñen máis actuacións por mor das numerosas festas que se celebran na comunidade galega a partir do mes de marzo e que, loxicamente, se foron cancelando e, día tras día, se seguen a cancelar. A esta situación sobrevida e inesperada, hai que lle engadir o feito de que, ata o momento en que comeza a temporada, as orquestras realizan un grande investimento na contratación de artistas, na renovación do material que empregan nas actuacións, na compra e arranxo de instrumentos etc. Estes cartos xa investidos non se poden recuperar se non teñen ningún ingreso. $\mathrm{O}$ máis urxente nestes momentos sería poder manter toda a súa infraestrutura para reducir no posible os gastos cando chegue o momento de retomar a actividade.

Segundo Manuel Fariña, a situación é moi difícil de resolver porque depende fundamentalmente da evolución da pandemia e das decisións das autoridades sanitarias ao respecto. Para o presidente da AGO, é importante, en primeiro lugar, distinguir o que é unha festa do que é un concerto e, polo tanto, considera que non se deben establecer os mesmos criterios en termos de cabida nos recintos onde se desenvolven. Unha festa popular, tal como se coñece en Galicia, é un evento no que se concentra moita xente, non só dunha vila ou dunha aldea, senón de toda unha comarca e, polo tanto, é a xuntanza máis social que hai en Galicia. Non se trata dun concerto onde a xente pode ir exclusivamente a mirar ou escoitar música, senón que o público participa e interactúa entre si, o que dificulta o establecemento das medidas de seguridade. En consecuencia, a súa celebración pode crear problemas ás comisións de festas, que son as entidades privadas que se ocupan ao longo de todo o ano de recadar os fondos necesarios para a súa organización, así como para a propia contratación das orquestras, unha xestión que normalmente se realiza entre os meses de abril e xuño para as festas do verán, agás no caso das máis demandadas, que se contratan aínda con máis antelación. No norte de España, onde se inclúe Galicia, Asturias, Cantabria e O Bierzo, esta é a forma de organizar as festas, a través das comisións. Tamén, comenta Fariña, hai casos de vilas máis grandes, onde o sentimento identitario da súa poboación coa vila non é tan forte como nunha aldea ou pequena poboación, non hai ese sentido de pertenza a un territorio e, polo tanto, a cidadanía e os negocios non se ven 
comprometidos economicamente coas festas locais. Neste tipo de vilas é o propio Concello o que asume a organización das festas.

Unha orquestra en Galicia pode ter unha media de dez actuacións por mes no verán, pero a estas alturas as comisións non teñen feitos os contratos pola inseguridade que provoca esta situación. Outro problema engadido co que se enfrontan refírese aos orzamentos das celebracións, que poden verse moi minguados ao non poder recadar cartos, como é habitual, a través dos bares ou negocios das vilas ou aldeas xa que desde a declaración do estado de alarma estiveron pechados e, polo tanto, ao non ter ingresos non se atopan nunha situación favorable para axudar economicamente nas festas.

O sector das orquestras en Galicia aglutina a unhas 7.000 persoas entre emprego directo e indirecto e xera un volume de negocio total duns 300 millóns de euros ao ano, explica o presidente da Asociación Galega de Orquestras, pero aínda se pode incrementar moito máis se se inclúen todos os negocios que se activan ao redor da organización das festas, como poden ser a pirotecnia, a montaxe de carpas, os xeradores de electricidade, que viven directamente da celebración das festas. Tamén hai outros sectores que indirectamente se benefician da organización das festas. Así, por exemplo, calculan que unha casa nun día de festa pode chegar a gastar unha media de entre 300 e 1.000 euros. Ademais, as festas xeran moito movemento de persoas, xa non só nun municipio turístico como pode ser Sanxenxo, senón tamén en municipios de interior como A Pontenova, que poden multiplicar por cinco a súa poboación durante as festas. Outro exemplo é Mondoñedo, que ten unha grande actividade coa celebración da Feira Medieval, a San Lucas e As Quendas.

Neste momento, na medida do posible, algunhas das actuacións das orquestras están adiándose para o vindeiro ano 2021, pero tamén hai moitos casos en que houbo que optar pola cancelación, o que implica que un $45 \%$ das orquestras galegas se tivesen que acoller a un ERTE. Unha das queixas máis importantes do sector das orquestras, neste senso, é que as empresas non poden pedir moratorias para os seus créditos ata volver comezar a retomar a actividade, sinala Manuel Fariña. Outra está relacionada coa falta de axudas públicas, ignorando deste xeito o innegable papel que teñen as orquestras como creadoras de postos de traballo e de dinamización socioeconómica e turística.

Tamén comenta Manuel Fariña que a Administración autonómica ten varias débedas coas orquestras. Unha está relacionada coa Lei de Espectáculos 
Públicos e Actividades Recreativas de Galicia ${ }^{12}$, na que non están incluídas as orquestras, malia que na comunidade galega as verbenas xeran unhas 5.000 actuacións ao ano, e outra co I Convenio Colectivo do Sector das Orquestras de Verbena en Galicia ${ }^{13}$, un convenio que non se está a acatar por parte das empresas contratantes e de cuxo cumprimento se está a desentender a propia Xunta de Galicia.

Para o presidente da Asociación Galega de Orquestras, a celebración do Xacobeo 2021 configúrase como un punto de esperanza de cara ao futuro máis inmediato, sobre todo pola oportunidade que lle pode brindar ao sector na obtención dalgún tipo de axuda por parte da Administración galega. Fariña incide en que as festas e verbenas se constitúen como parte dun patrimonio cultural moi relevante en Galicia, cun contido moi atraente tanto para os turistas como para os peregrinos.

\section{Conclusións}

A música é un dos grandes sectores da cultura galega. A conta satélite do IGE estima que xunto co resto das artes escénicas supón o 12,9\% do total do peso económico da cultura. Se se ten en conta a evolución dos datos referidos á actividade da música popular, obsérvase como creceu en espectadores e recadación ata 2010, último ano Xacobeo, e se reduciu despois con brusquidade, para empezar a recuperarse lentamente a partir de datas recentes. No último ano de referencia (2018), organizáronse en Galicia un total de 3.585 concertos, aos que asistiron 1.463 .170 persoas. A irrupción dos grandes festivais e, máis recentemente, a redución que implica o chamado IVE cultural impulsaron a recadación da música popular. Pese a que as e os galegos gastan menos en cultura que antes da crise de 2008, o gasto medio por espectador no total das actividades de música popular ao vivo en Galicia non parou de medrar; nos últimos cinco anos practicamente se duplicou a cantidade (de 5,5 $€$ en 2013 a 10,7 € en 2018). No ano 2018 obtívose unha recadación total de 15.634.633 euros, o que supón un incremento do 22,7\% respecto de 2017.

O gasto público da AGADIC, despois dun descenso importante, apunta unha lixeira recuperación (nos orzamentos de 2020 destínanse 7,4 millóns de euros a investimentos), á vez que se incrementa dunha maneira importante nos últimos anos o gasto da Administración local destinada a festexos (que inclúen

\footnotetext{
${ }^{12}$ Lei 10/2017, do 27 de decembro.

${ }^{13}$ Resolución do 9 de xaneiro de 2017, da Secretaría Xeral de Emprego.
} 
a contratación de espectáculos musicais), para situarse en 28,9 millóns de euros no último ano de referencia (2017).

Este aumento do gasto público xustifícase en parte polo impacto económico que xera a música en vivo. Por exemplo, o retorno de investimento calculado a partir da suma dos importes das axudas e subvencións da Xunta de Galicia a festivais de música é maior canto maior é o evento, e nos máis grandes mesmo supera os 180 euros por euro investido.

Tamén son moi importantes outros axentes musicais que adquiren unha relevancia especial en Galicia. É o caso das orquestras, das bandas de música populares e das agrupacións de música tradicional galega. A actividade que se xera ao redor delas é dunha gran relevancia social, cun importante impacto económico e laboral.

As e os representantes das principais asociacións profesionais da música popular galega coinciden en que a situación provocada pola aparición do coronavirus tivo un impacto moi destacable no sector, con graves consecuencias económicas. As medidas de prevención de contaxios e distanciamento social decretadas ou que se poden intuír nun futuro próximo son incompatibles co papel socializador dos eventos musicais ao vivo, onde non só se vai escoitar música, senón tamén interactuar con outras persoas.

Para cando se volva programar música en vivo e coa previsión de que se limite considerablemente a afluencia de público, dun xeito ou doutro, estes representantes solicitan achegas económicas da Administración. Malia esta petición, tamén se detecta un desexo de independencia para evitar ser unha actividade subvencionada que mesmo considerarían prexudicial. En relación con isto, reivindícase unha política cultural afastada da gratuidade porque non resultaría un estímulo sostible, polo que se avoga por unha política de prezos para a cultura que fomente unha industria que no futuro teña maior capacidade para enfrontarse a períodos críticos como o presente. Tamén se detectaron algunhas prevencións cara á inxección directa de capitais pola tendencia á concentración en poucas corporacións que esta práctica pode supoñer.

Este impacto económico negativo ten unhas consecuencias laborais directas que comparte todo o sector. Antes da aparición da crise, practicamente a totalidade dos e das artistas deste colectivo percibían os seus ingresos de actuacións en vivo. A produción discográfica e os dereitos das plataformas dixitais constituían unha parte moi pequena deles. Para algúns dos responsables do sector, a música popular sofre unha situación de precariedade estrutural. De feito, determinados problemas laborais teñen a súa orixe no pasado e débense, entre outras cuestións, a unha falta de regulación específica. 
A precariedade en que se atopan algúns músicos mesmo implica non ter dereito a percibir as prestacións deseñadas para paliar a actual crise, polo que teñen que acudir a axudas de protección social básica. Aínda que a situación laboral das persoas que traballan neste sector varía moito, cabe destacar que moitos artistas e técnicos teñen unha economía persoal que non lles permite un aforro para facer fronte a imprevistos. Algúns dos entrevistados e entrevistadas denuncian que nunca se valorou o seu traballo como acontece noutros países. Ás carencias de regulación laboral hai que engadir tamén a falta dun sistema educativo con formación pública regrada e dun marco fiscal de tributación adaptado á súa singularidade.

Outras demandas da música popular que se recollen neste traballo son fomentar o tecido produtivo a través de proxectos de colaboración, a dotación de fondos para a creación dos artistas ou o estímulo de actividades culturais locais. Con todo, recoñécese que os problemas da música popular son moi diversos e unha norma xeral non resolverá todas as situacións particulares.

Esta diversidade é facilmente observable cando se analiza polo miúdo o estado dos diferentes colectivos profesionais. No caso dos músicos asociados arredor da entidade Músicas ao Vivo, dende marzo ata este momento a cancelación de actuacións programadas reduciu a actividade destes profesionais a algunha gravación esporádica ou algún concerto en liña, polo que os ingresos desapareceron na práctica. Dende este colectivo preséntase unha demanda moi xenérica, pero que entenden que é fundamental: que todas as administracións aposten pola cultura de base para afondar na profesionalización a través dunha xestión coordinada e despolitizada.

A actividade das salas de concertos, segundo os seus responsables, foi case sempre deficitaria, movida principalmente polo voluntarismo dos promotores. Este tipo de negocios, pese a non ter ingresos neste momento, segue soportando gastos correntes, principalmente os alugueiros. As necesidades principais deste colectivo pasan por algún tipo de marco que permita sufragar os gastos durante o tempo que duren as medidas sanitarias e suplemente a caída de ingresos que se prevé ata volver a unha situación de normalidade. Tamén advirten que as medidas que poidan supoñer a redución de cabida implican a práctica inviabilidade da súa actividade.

Pese a que dende Asociación Empresarial Festivais de Galicia sinalan que na actualidade non se sabe de maneira oficial que festivais se van poder realizar, o ritmo de cancelacións no que vai de temporada e as limitacións de cabida previstas indican que 2020 será un ano moi difícil para programar eventos deste tipo. Existe unha grande incerteza, porque non se coñecen os protocolos de medidas preventivas que habería que adoptar tanto para o 
persoal traballador como para o público. Así mesmo, a solicitude dos créditos que ofreceu a Administración para algunhas empresas promotoras de festivais pode frustrarse ao ser consideradas entidades de risco, dado que unha única cancelación pode supoñer dous anos sen ingresos. Demandan unha normativa que facilite a cancelación de eventos programados e flexibilidade para a devolución das entradas vendidas.

Para as orquestras, que segundo os seus representantes en Galicia aglutinan a unhas 7.000 persoas con emprego directo e indirecto e xeran un volume de negocio total duns 300 millóns de euros ao ano, a crise sanitaria produciuse xustamente na época en que teñen máis actuacións por mor das numerosas festas que se celebran a partir do mes de marzo, xuntando cancelacións con ausencia de contratacións para o que queda de temporada. Ademais isto coincide no momento en que este tipo de entidades fan o investimento máis grande da temporada nos diferentes equipamentos que precisan para a súa actividade. Para este colectivo profesional é imprescindible poder manter a súa infraestrutura para cando se volvan organizar festas e verbenas. Os seus representantes demandan algún tipo de tratamento específico no relativo ás medidas sanitarias, dado que ás celebracións populares non se lles poden aplicar as limitacións pensadas para concertos ou outro tipo de concentracións e porque a súa organización depende principalmente de entidades privadas de tipo asociativo. Outra demanda específica é que as axudas das administracións deben dirixirse aos e ás profesionais.

Outros colectivos, como o das bandas de música populares, das que a pesar da súa natureza amadora dependen uns 300 postos de traballo, estiman nunha avaliación preliminar unha baixada de ingresos de polo menos o $42 \%$ para 2020.

Durante as semanas de confinamento decretadas polo Goberno, os músicos tiveron unha presenza importante nas redes sociais e en Internet, ofrecendo música de balde. Este tipo de accións, que tiveron un efecto positivo para a sociedade no seu conxunto e mesmo para os propios músicos, tamén merecen atención neste traballo. En xeral, para o público da música en directo o streaming non é exactamente unha alternativa porque este tipo de contidos en moitos casos non ten a calidade suficiente. Tamén se producen algúns problemas de índole legal con estas difusións. Non obstante, un streaming de calidade e legal, mesmo delimitado xeograficamente, pode ser unha solución temporal para executar contratos en vigor coas administracións e fornecer de ingresos a músicos e compañías.

En canto á reacción da Administración, as percepcións son dispares. Algúns dos entrevistados consideran que en xeral a cultura ten unha posición 
marxinal nas prioridades políticas. Noutros casos, estímase que a resposta foi positiva e proactiva, pese a que a capacidade de acción sexa limitada. De feito, a estratexia da Xunta de Galicia de fortalecer o vindeiro Xacobeo percíbese como unha esperanza para todo o sector. Apúntase como unha oportunidade para canalizar axudas para empresas e artistas galegos, pero tamén como un acicate para o turismo e a cultura. Tamén se detectan voces críticas, que pensan que se lle está a dar demasiada importancia ao Xacobeo, ao introducir neste a maior parte das medidas de protección. Os diferentes actores que compoñen o sector apuntan á necesidade de que as axudas sexan transversais e non se dirixan unicamente a un tipo de evento ou celebración concreta. Sinalan a importancia dunha colaboración proactiva, co fin de ofrecer unha oferta suficientemente atractiva a todos os niveis e protexer o patrimonio cultural propio, máis que pensar en grandes estrelas do panorama internacional.

Para os máis optimistas, a crise presenta unha oportunidade, polo que se invoca a creatividade para desenvolver proxectos alternativos aos que ofreceu a música popular ata este momento. Avógase por aproveitar a situación crítica para dar visibilidade a problemas que nunca estiveron na axenda política e, así, impulsar o contido e a xestión do sector da música popular, incidindo na capacidade dinamizadora que ten para outros sectores. A partir dunha fase de rescate e un plan de recuperación posterior, un gran pacto de todo o sector da música, con conexións nacionais e internacionais, podería ser un acicate do desenvolvemento económico e social de Galicia nos vindeiros anos. 